\title{
The Effect of Homeownership on Geographic Mobility and Labor Market Outcomes*
}

\author{
Hernan Winkler ${ }^{\dagger}$ \\ UCLA \\ JOB MARKET PAPER
}

December 6, 2010

\begin{abstract}
This paper examines the effect of homeownership on mobility and labor income and provides new evidence that owning a home makes workers less likely to move in response to labor market shocks. To identify this effect, I develop and estimate a structural dynamic model of housing choices, migration decisions and labor market outcomes. I find that owning a home has a large negative effect on the probability of moving in response to a labor market shock and a small negative effect on labor income. Owners suffering from a decrease in home equity are 40 percent less mobile. I conduct two policy experiments. The first shows that the home mortgage deduction has a positive effect on homeownership, affects mobility and creates an incentive to buy larger houses. Second, I find that if the down payment requirement for buying a home is eliminated, homeownership exhibits a large increase, while the mobility and labor income of households experiencing negative labor market shocks decrease.
\end{abstract}

Keywords: Homeownership, Mobility, Labor Markets, Structural Model

\footnotetext{
${ }^{*}$ The latest version of this paper can always be found at the following URL: http://hernanwinkler.weebly.com/research.html. I am grateful to Moshe Buchinsky, Leah Platt Boustan, Matthew Kahn and Maria Casanova for their guidance and support. I also thank Maurizio Mazzocco, Claudia Ruiz, Alvaro Mezza and participants at the UCLA Applied Micro seminar for helpful comments. I gratefullly acknowledge the UCLA Ziman Center for Real Estate for financial support.

†hwinkler@ucla.edu
} 


\section{Introduction}

Substantial public resources are used to subsidize homeownership in the United States. In 2009, the federal government lost 146 billion dollars in potential tax revenue to home mortgage interest and property tax deductions, and capital gains tax exclusions on home sales. ${ }^{1}$ The usual justification for these subsidies is that homeownership has positive externalities (Glaeser and Shapiro (2003)). For instance, homeownership may encourage investment in local amenities and social capital because homeowners tend to spend more years in a community than do renters and community quality is capitalized into home values (DiPasquale and Glaeser (1999)). These positive effects, however, must be weighed against the potentially negative effects of homeownership on mobility and labor market outcomes. In particular, because of the high transaction costs associated with homeownership, homeowners may be less inclined to move in response to economic shocks or more attractive job offers (Oswald (1996)). This paper develops and estimates the first structural dynamic model of housing choices, residential location and labor market outcomes to estimate the effect of homeownership on geographic mobility and labor income.

Previous attempts to estimate this effect have used renters as the control group for homeowners or have used aggregate data. ${ }^{2}$ In this paper I argue that both approaches are misleading because renters are not comparable to homeowners and aggregate data studies are usually affected by omitted variable and measurement error biases. By explicitly modeling housing and migration choices the results of this paper control for omitted variables and reverse causality issues that affect existing empirical evidence.

In the model, households maximize their lifetime utility by choosing whether to own or rent a house, where to live, how much to save and how much to spend on housing services. The model includes several channels that could be driving the observed relationship between homeownership, mobility and labor income. Specifically, the decision to buy a home is affected by the following factors in the model: liquidity constraints, expected mobility, home price appreciation, access to a home equity line of credit, tax benefits and having more discretion over the way the house is used and modified. At the same time, mobility decisions are affected by job offers from other locations, wage shocks, housing shocks, moving costs and geographic differences in home values, rents and wages. Because unobservable individual traits may affect both housing and mobility decisions, I also

\footnotetext{
${ }^{1}$ Figure obtained from the Budget of the U.S. Government, Fiscal year 2010, Office of Management and Budget. This figure does not include the implicit federal subsidy to the three government-sponsored housing enterprises (such as Fannie Mae), which was 23 billion dollars in 2003 (Congressional Budget Office (2004))

${ }^{2}$ See Dietz and Haurin (2003) for a literature review.
} 
control for unobserved heterogeneity.

The current number of children as well as expectations regarding future family size are included in the model because mobility and housing decisions are likely to be affected by fertility choices. The current number of children has a direct effect on utility because consumption and housing services enter the utility function in per capita terms. The number of children also affects transaction costs indirectly. As family size increases, house size must also increase in order to maintain a given level of utility. Moving expenses are also allowed to vary with the number of children.

I estimate the model using the Panel Survey of Income Dynamics (PSID) from 1984 to 1997 and use the model to assess the extent to which transaction costs affect migration choices and labor market outcomes. To do this, I assume that homeowners face an unexpected elimination of transaction costs at the time of receiving a labor market shock. In this way, I can compare the actual choices of homeowners to the choices they would make in a counterfactual scenario where they had the same moving costs as renters. I find that owning a home at the time of receiving a negative labor market shock decreases the probability of moving by a third. Owning a home also decreases the likelihood of taking a more attractive job offer in a different location. Therefore, homeownership has a negative effect on labor income through these channels. I also find that homeowners suffering from a decrease in home equity are less likely to move to another location, thereby exacerbating the effect of negative labor market shocks on their labor income. Another important result is that the estimated effect of homeownership on mobility is considerably smaller than suggested by comparing homeowners against renters.

Estimating structural parameters allows me to quantify the effect of different policy experiments on mobility and labor income. Using the model, it is possible to generate a simulated dataset where individuals who optimally chose to buy a house in the real data may instead choose to rent under a different set of incentives, that is, I use the model to generate a control group for homeowners. I estimate the impact of two policy changes on housing choices, mobility and income. First, I assume that the tax deduction on mortgage interest payments is eliminated. I find that eliminating this tax incentive decreases homeownership and affects mobility choices. In addition, I find that the average house size decreases, i.e., the deduction introduces an incentive to buy bigger homes.

Second, motivated by recent changes in the housing market, I examine the effects of eliminating the down payment requirement. This policy has a substantial effect on homeownership and mobility. In particular, the probability of owning a home increases dramatically and the mobility rate of lowincome households increases, as they become less liquidity constrained to afford a move. In contrast, 
the mobility rate of higher-income households decreases, as they buy larger homes in their current location, thereby increasing their moving costs. In addition, the average mobility and labor income decreases among all households experiencing negative labor market shocks.

This paper makes three contributions. First, it develops and estimates a novel structural dynamic model of housing choices, residential location and labor market outcomes. This paper demonstrates that a very rich econometric model of optimal dynamic migration and housing decisions is feasible and capable of matching the main features of the data. Second, this paper shows that owning a home has a negative effect on mobility and labor income while controlling for the potential reverse causality and endogeneity issues that affect existing empirical studies. Having a consistent estimate of this effect is relevant for policies that affect the housing market, as they could otherwise have unintended consequences on individuals' mobility choices and job market careers. Finally, this is the first paper to show that changes in the home mortgage interest deduction and the down payment requirement affect geographic mobility and labor market outcomes. Hence, this paper contributes to the current debate about the effects of these policy instruments on the economy.

The results of this paper contribute to the literature on how regions adjust to shocks. Blanchard and Katz (1992) find that most of the adjustment of states to shocks is through movements of labor. This paper shows that homeownership slows down the adjustment process after a labor market shock. This paper also provides empirical support for macroeconomic models of mismatch in the labor market. For instance, to explain why unemployment and job vacancies coexist, Shimer (2007) develops a theory of mismatch where unemployed workers are attached to an occupation and a geographic location in which jobs are currently scarce. In this paper, I find that household heads may reject better job offers from other regions if the moving cost - which includes both out-of-pocket expenses and the loss of a region-specific utility premium - is too high. Finally, this paper contributes to the literature on the positive effects of homeownership. In a well-known study, DiPasquale and Glaeser (1999) claim that homeownership gives individuals an incentive to invest in social capital because homeownership creates barriers to mobility. The authors reach this conclusion by using renters as the comparison group. However, I find that using renters as the control group over-estimates the impact of homeownership on mobility. As a result, using renters as the control group may also overestimate the effect of homeownership on the incentives to invest in social capital.

The remainder of the paper proceeds as follows. Section 2 motivates the paper by showing that its main hypothesis is at the core of the current debate about the role of homeownership in the United States and briefly describes the previous attempts to estimate the effect of homeownership on labor 
market outcomes. Section 3 describes the data used in this paper and shows some descriptive statistics to highlight the mechanisms that might be driving these empirical facts, which will be included in the structural model. Section 4 presents the structural model, Section 5 outlines the solution method and Section 6 describes the estimation process as well as the fit and the robustness of the model. Section 7 uses the model to generate counterfactual scenarios to assess the effect of homeownership on mobility and labor income. Section 8 conducts policy experiments considering the effect of liquidity constraints and the home mortgage interest deduction on homeownership, mobility and labor income. Finally, Section 9 concludes.

\section{Motivation and Literature Review}

Government efforts to increase homeownership are often justified with reference to a large body of literature that documents an association between homeownership and positive socioeconomic outcomes. In a well-known study, DiPasquale and Glaeser (1999) claim that homeownership encourages investment in local amenities and social capital. The authors reach this conclusion by estimating OLS regressions using externality-creating variables as the dependent variables and home tenure status as the explanatory variable. ${ }^{3}$ Haurin, Parcel, and Haurin (2002) and Green and White (1997) claim that homeownership has a positive effect on children and teenagers human capital. All of the above papers argue that a large portion of these positive effects of homeownership arise from the lower mobility of homeowners. ${ }^{4}$

During the recent housing crisis, however, scholars and the media have raised concerns that homeownership may add some frictions to the labor market, thereby slowing recovery. ${ }^{5}$ This hypothesis has been previously tested in the literature. In a seminal paper, Oswald (1996) claimed that the high unemployment of the Western economies has been produced by the rise of homeownership.

\footnotetext{
${ }^{3}$ The authors also estimate these equations using an instrument for homeownership status. However, as the authors also recognize, the instrument has some limitations.

${ }^{4}$ In addition, homeownership is associated with greater political and social activity ( Glaeser and Sacerdote (2000)), lower crime rates (Alba, Logan, and Bellair (1994)), better physical health (Macintyre, Ellaway, Der, Ford, and Hunt (1998)). See Dietz and Haurin (2003) for a literature review.

${ }^{5}$ For instance, Paul Krugman has expressed this view in his New York Times column, stating, "(...) the costs and hassle of selling one home and buying another (...) tend to make workers reluctant to go where the jobs are (...). Right now, economic distress is concentrated in the states with the biggest housing busts: Florida and California have experienced much steeper rises in unemployment than the nation as a whole." See also Narayana Kocherlakota's speech "Back Inside the FOMC" (September 8, 2010 ), "The Case Against Homeownership" (Time Magazine, September 6, 2010), "Homeownership is Overrated" (The Wall Street Journal (Eastern Edition), June 7, 2010), "The Road Not Taken" (The Economist, March 26, 2009), "Home Not-So-Sweet Home" (The New York Times, June 23, 2008), "Buy a house, Lose Your Job?" (Slate, November 7, 1997), "Homeownership's Downsides" (The Atlantic, July 2, 2009), "Housebound" (The Atlantic, December 7, 2007), "Oh, Give Me a Home Without a Subsidized Loan" (The Christian Science Monitor, October 2, 2009)
} 
He estimates cross-country regressions and cross-state regressions for the U.S. and finds that a 10 percentage point rise in homeownership is associated with a 2 point increase in the unemployment rate. This hypothesis has also been tested using micro data. Green and Hendershott (2001) find that homeowners who become unemployed find work less quickly than renters. Most of the empirical evidence, however, shows that homeowners have lower unemployment rates and higher wages than renters. ${ }^{6}$

Existing empirical evidence has some limitations. First, studies using aggregate data are usually affected by omitted variable and measurement error biases. More specifically, the correlation between countries' unemployment and homeownership rates might be driven by variables that are difficult to measure or that are unobservable to the researcher, such as housing and labor market policies. In addition, the fact that aggregate variables are usually measured with error might introduce a bias in the estimates. Second, papers using micro data implicitly define renters as the control group for homeowners. In section 3 I show that renters are different from homeowners in several aspects, suggesting that they are not a good control group for homeowners.

To my knowledge, this is the first paper that provides an estimate of the causal effect of homeownership on mobility and labor market outcomes that does not use aggregate data or renters as the comparison group.

In contrast to previous structural dynamic models of housing choices, I assume that labor income is endogenous and to control for the effect of selective migration I estimate the income process simultaneously with other structural parameters. Bajari, Chan, Krueger, and Miller (2009) and Li, Liu, and Yao (2009) estimate structural dynamic models of housing demand, but estimate the income process separately from other structural parameters. While this paper emphasizes the relationship between housing and migration choices, Bajari, Chan, Krueger, and Miller (2009) and Li, Liu, and Yao (2009) include mobility but only as an exogenous shock; that is, households do not choose where to move.

This model improves on previous work by introducing geographic differences in housing prices as an incentive for migration decisions. Kennan and Walker (2003) estimate a structural dynamic model of migration decisions and find that location choices are substantially affected by income prospects. However, their model does not include housing choices. This paper is closely related to Gemici (2007) in terms of general approach, but while this paper chooses a unitary model of household migration, Gemici (2007) shows that intra-household bargaining is an important determinant

\footnotetext{
${ }^{6}$ See Coulson and Fisher (2009), Coulson and Fisher (2002), Munch, Rosholm, and Svarer (2008) and Van Leuvensteijn and Koning (2004)
} 
of migration decisions. However, Gemici (2007) does not consider the link between housing and migration choices.

This paper is also related to Kaplan (2009) as both study the connection between labor market risk and individuals' living arrangements at different points of the life cycle. While Kaplan (2009) finds that the option to move in and out of the parental home is an important insurance against labor market risk for youths, I find that home tenure and house size choices affect the way married households cope with labor market shocks.

\section{Homeownership, Mobility and Labor Market Outcomes}

This section provides descriptive statistics on homeownership, mobility and labor market outcomes. Throughout the paper I use data from the Panel Survey of Income Dynamics (PSID) from 1980 to 1997, and restrict the sample to households whose head is male, white and between 25 and 50 years old. Because changes in marital status are likely to have an impact on both migration and housing choices, I only keep households who are always married while in the sample. Section 3.1 shows that homeowners are different from renters in every variable considered. In addition, it shows that there are significant changes in key economic variables as households make the transition from renting to owning a house. Section 3.2 presents some suggestive evidence that renters respond more flexibly to labor market shocks than do homeowners. Finally, Section 3.3 summarizes possible mechanisms driving the observed patterns and briefly outlines the basic elements of the structural model developed in section 4 .

\subsection{Homeowners and Renters}

Table 1 shows different characteristics of homeowners and renters. The first two columns report sample averages and the third one shows the difference in means and standard errors. All the differences are statistically different from zero, that is, homeowners are different from renters in every variable considered. Homeowners have higher levels of education, are older and have more savings than renters. They have higher incomes, lower unemployment rates and change jobs less frequently. They have more children and live in larger houses, and the number of rooms per person is larger. Finally, homeowners' mobility rates are considerably lower than those of renters. For instance, while the probability of an inter-state move is 7.7 percent for renters, that figure for homeowners is only 2 
percent. $^{7}$

However, individuals who eventually become homeowners are not always richer and less mobile than renters. In fact, these differences exhibit significant variation over the life cycle. Figure 1 plots transitions in mobility, income and fertility as households make the transition from renting to owning a house. ${ }^{8}$ To facilitate comparisons, the same statistics are computed for individuals who always rented or owned a house over the period. ${ }^{9}$ Figure 1 (a) shows that mobility rates sharply drop when households become homeowners. ${ }^{10}$ This pattern is also observed when using a definition of mobility that includes only long distance moves. Figure 1 (b) shows that the probability of an inter-State move decreases when households become homeowners. Figure 1 (c) shows that this transition is reflected in job mobility, defined as the share of households heads who change jobs during the past year, although the transition is smoother.

Figures 1 (d), (e) and (f) show changes in the head's labor income and total household labor income. Before buying a house, households who eventually become homeowners have income levels similar to those of households who always rent. However, they experience significant income growth as they make the transition to homeownership. Eventually, these new homeowners catch up with households who always owned a house throughout the sample period and at that point their income growth decreases.

To check if these transitions are driven by fertility, Figure 1 (g) plots the number of children during the transition to homeownership. While there is a large increase in the number of children after buying a house, the differences between the transition sample and those who always own or rent are smaller in magnitude when compared to the transitions in income and mobility. In fact, the three groups seem to experience the same transition over time.

In summary, homeowners move less and are better off than renters in several socioeconomic characteristics. Before transitioning to homeownership, homeowners experience an increase in labor income. After buying a house, mobility and income growth both decline.

\footnotetext{
${ }^{7}$ These results still hold if I restrict the sample to individuals less than 35 years old; that is, they are not driven by life cycle patterns only.

${ }^{8}$ Because households become homeowners in different years, the number of observations is not constant along the horizontal axis. For instance, for an individual who becomes homeowner in the second year of the sample, an observation for 10 years before buying a house is not available.

${ }^{9}$ Age averages were translated into "years relative to home buying" averages by weighting the age averages. For instance, if 30 percent of the individuals were 30 years old two years before buying a house, and 70 percent of the individuals were 35 years old two years before buying a house, then the appropriate comparison group of those who eventually make the transition from renting to owning a home is a sample with 30 percent of 30 -year-old individuals and 70 percent of 35-year-old individuals.

${ }^{10}$ This variable is computed using responses to question "Have you (HEAD) moved any time since the spring of (Year)?" in the PSID. This definition of mobility includes both short and long distance moves.
} 


\subsection{Labor Market Shocks}

To examine the causal relationship between homeownership and mobility we need to consider an appropriate control group for homeowners. That is, we need a group of individuals who share the same observable and unobservable characteristics as homeowners with the exception of their home tenure choice. In this section, I estimate the different response to negative labor market shocks among homeowners and renters while holding characteristics such as number of children, age and timeinvariant unobserved heterogeneity constant. In section 7, I show that the structural model replicates the results from this section. I also show that reduced-form estimates using renters as the control group are biased, that is, the estimated effects are different when using the counterfactual generated by the model.

Following Krueger and Summers (1988) I define a negative labor market shock as losing a job because the company folded or the individual was laid off. ${ }^{11}$ It is important to note that the paper proposes not only that homeowners are less able to move away from negative labor market shocks, but also that they are less able to move in response to job offers in other locations. However, I do not consider the effect of positive labor income shocks in this section because only accepted job offers are observed. ${ }^{12}$

Table 2 shows the parameter estimates of the following linear model:

$$
\begin{aligned}
y_{i, t}= & \beta_{0}+\beta_{1, t_{0}} \text { shock }_{i, t=t_{0}}+\beta_{1, t \geq t_{0+1}} \text { shock }_{i, t \geq t_{0}+1}+ \\
& +\beta_{2, t_{0}} \text { shock }_{i, t=t_{0}} \cdot \text { home_owner }_{i, t_{0}}+\beta_{2, t \geq t_{0}+1} \text { shock }_{i, t \geq t_{0+1}} \cdot \text { home_owner }_{i, t_{0}}+ \\
& +\beta_{3} \text { home_owner }_{i, t}+\Gamma X+\varepsilon_{i, t},
\end{aligned}
$$

where home_owner ${ }_{i, t}$ is a dummy variable equal to one if the household is a homeowner. The variable $s h o c k_{i, k}$ is a dummy variable equal to one in the year in which the household head loses his job ( $\left.k=t_{0}\right)$ or one year or more after the job loss $\left(k=t_{0}+1\right)$. The coefficients $\beta_{1, k}$ reflect the change in the dependent variable for renters $k$ periods after the shock. The coefficients $\beta_{2, k}$ capture the differential change in $y_{i, t}$ for homeowners. To control for other factors that could be correlated with both mobility and homeownership status, the vector $X$ contains a set of individual characteristics

\footnotetext{
${ }^{11}$ More specifically, I use the response to the question "What happened with that employer-did the company go out of business, were you laid off, did you quit, or what?" in the PSID. I define a negative labor market shock as losing a job because the "Company folded/changed hands/moved out of town; employer died/went out of business" or the individual was "Laid off; fired".

${ }^{12}$ In the structural model, I estimate the data generating process of both negative and positive labor market shocks.
} 
such as age, number of children and household fixed effects. The sample also includes individuals who were not subject to negative labor market shocks as controls. Equation (1) is estimated using different dependent variables $y_{i, t}$. First, I use three different measures of mobility: the first measure of mobility is any type of move, the second only considers inter-state moves and the third reflects moves across Census Divisions. Second, I use the following labor market variables as the dependent variables: unemployment status and log total labor income.

Table 2 shows that owners have substantially lower mobility rates than renters and that they are less likely to move at the time of receiving a labor market shock. This result holds for the three measures of mobility. The probability of remaining unemployed is not statistically different from the pre-shock level one or more years after the shock for renters. In contrast, the shock seems to have a permanent effect on homeowners' unemployment: one or more years after the shock, homeowners' unemployment rate is almost 6 percentage points higher than the pre-shock value. Accordingly, the effect of the shock on labor income seems to be stronger for homeowners.

The results from this exercise do not prove that homeownership makes individuals less able to respond to labor market shocks, but they do show that it takes more time for homeowners to recover from the shock. However, this might be the effect of homeownership itself or the effect of unobservable variables that are correlated with both the decision to buy a house and the way individuals respond to shocks. For instance, individuals who have low expected mobility, even after controlling for time-invariant unobserved heterogeneity, age and number of children, might be more likely to own homes and move less. The model in section 4 tries to overcome this limitation.

\subsection{Summary of Key Facts}

This section summarizes the previous results and outlines the mechanisms that could be driving these patterns. These mechanisms will be included in the structural model. First, homeowners are wealthier and have higher incomes than renters. These facts are consistent with the idea that if individuals are liquidity constrained, those with higher incomes and wealth would be more likely to buy a house. In addition, labor income growth, job and geographic mobility are higher prior to homeownership. This pattern is consistent with the idea that prior to ownership, households increase work effort and earnings to save for the down payment (Dietz and Haurin (2003)).

Second, individuals experience a sharp and permanent decrease in mobility after buying a house. Because the transaction costs of buying and selling a house are substantial, individuals would be 
more likely to buy a house if their expected mobility were low. The fact that job mobility starts to fall before buying a house also suggests that expectations regarding job stability are important in the decision to become a homeowner. At the same time, negative labor market shocks seem to have a permanent effect on homeowners but not on renters. This is consistent with the idea that individuals with lower moving costs would have greater flexibility to move away from a negative shock or to move in response to a job offer in another region.

Third, the transition in fertility is related to transitions in labor income and mobility over the life cycle. This is consistent with the idea that a larger family might incurr higher moving costs. In addition, a larger family might require a bigger house to mantain the level of housing services per capita, and transaction costs are usually a fraction of the value of the house.

In light of the previous evidence, the structural model of housing consumption, migration decisions and labor market outcomes developed in the next section includes liquidity constraints, transaction and moving costs, family size, income and housing uncertainty, inter-region job offers as well as expectations regarding future mobility, income and housing prices.

\section{A Model of Housing, Migration and Labor Market Outcomes}

The model incorporates the decisions of married households, whose heads are between the ages of 25 and 50. Each period, households make decisions regarding their location, homeownership status, house size and savings. A period corresponds to a calendar year.

The model focuses on migration across Census Divisions in the United States, so that there are only nine locations households can reside in or move to. The next best alternative is to analyze crossstate moves. However, as seen in Table 3, most cross-state moves are also across regions: 18.7 percent and 14.2 percent of individuals move at least once across states and across regions, respectively. As a result, the additional gain in variation from using cross-state moves would be small, while the state space would be considerably larger. In addition, this definition of location is appropriate in order to study job-related moves. Table 3 shows that while only $21 \%$ of short-distance moves are motivated by employment considerations, $62 \%$ of cross-region moves are job-related.

I exclude households whose head is a non-white high school dropout for two reasons. First, their mobility rates are considerably lower than those of whites who are at least high school graduates. Second, their housing choices are also different from this last group. As a result, to consider their mobility and housing choices it is necessary to use a different definition of mobility (probably one 
that includes shorter-distance moves) and different equations for the housing market.

\subsection{Household's Problem}

Households derive utility from consumption and housing services. I assume that housing services are equivalent to rooms per capita. In addition, there is a "utility premium" if the household lives in the household head's birth location. Hence, households maximize lifetime expected utility:

$$
\sum_{t=t_{0}}^{T} \beta^{t-t_{0}} E\left[U\left(c_{t}, \text { rooms }_{t}, R_{B L t}\right)\right]
$$

where

$$
\begin{array}{ll}
c_{t}: & \text { Consumption per capita } \\
\text { rooms }_{t}: & \text { Number of rooms per capita } \\
R_{B L t}: & \text { Dummy variable }=1 \text { if lives in head's region of birth }
\end{array}
$$

The budget constraint is presented in Section 4.6. Following Bajari, Chan, Krueger, and Miller (2009) and Li, Liu, and Yao (2009), I assume that the utility function exhibits a constant elasticity of substitution (CES) between consumption goods and housing services. In particular,

$$
U\left(c, \text { rooms }, R_{B L}\right)=\frac{\left(a c^{1-\frac{1}{\eta}}+(1-a)(\kappa \cdot \text { rooms })^{1-\frac{1}{\eta}}\right)^{\frac{1-\sigma}{1-\frac{1}{\eta}}}}{1-\sigma}+b_{h} R_{B L}
$$

The parameter $a$ controls the expenditure share on housing services, and $\eta$ governs the degree of intra-temporal substitution between housing and consumption goods. Following Kiyotaki and Nikolov (2008) $\kappa$ is a parameter governing the taste for homeownership. In particular,

$$
\begin{aligned}
\kappa & =1 \text { if the household rents } \\
& >1 \text { if the household owns home }
\end{aligned}
$$

A value of $\kappa$ greater than one implies that households enjoy a higher utility from housing services if they own rather than rent their home. This parameter is included to capture certain benefits of homeownership such as owners' greater discretion over the way the house is used and modified according to their tastes. 
The parameter $b_{h}$ is the utility premium from living in the household head's region of birth. This parameter is indexed by $h$ because there is heterogeneity in the way households' value their location of birth. Specifically, I assume two types of households, that is

$$
b_{h}=\{0, \bar{b}\}
$$

where $\bar{b}>0$. The proportion of households with $b=0$ and $b=\bar{b}$ are $\pi_{b=0}$ and $1-\pi_{b=0}$, respectively. This parameter is intended to reflect the fact that even after controlling for observable variables, some individuals respond more than others to income and housing prices differentials across regions. Living in one's region of birth (or not) is a good proxy for this different propensity to move: In the data, individuals who reside in their region of birth are less likely to move than individuals who live outside.

\subsection{Geographic Mobility and Labor Income}

Household's labor income offer is determined by the following equation:

$$
\log \left(\text { income }_{h, t}\right)=\beta_{0}+\sum_{i=1}^{3} \beta_{e d u, i} e d u_{i, h}+\beta_{3} a g e_{h, t}+\beta_{4} a g e_{h, t}^{2}+\sum_{i=2}^{9} \beta_{R, i} R_{i, h, t}+\varepsilon_{h, t},
$$

where $e d u_{i, h}$ is a dummy variable indicating the level of education of the couple; specifically,

$$
\begin{aligned}
& e d u_{1, h}=1 \text { if head is a high school graduate and spouse is a college graduate } \\
& e d u_{2, h}=1 \text { if head is a college graduate and spouse is a high school graduate } \\
& e d u_{3, h}=1 \text { if both are college graduates. }
\end{aligned}
$$

The category with both the head and spouse being high school graduates is ommitted; age is the age of the household head and $R_{i, h, t}$ is a dummy variable indicating the region where the household lives. I assume the following process for the residual term:

$$
\varepsilon_{h, t}=\rho \varepsilon_{h, t-1}+v_{h, t},
$$

and the distribution of $v_{h, t}$ is normal so that $v_{h, t} \sim N\left(0, \sigma_{r}\right)$ for each location $r$. 
Households can move to another location only if they receive a job offer from that region. In each period, a household can receive only one job offer from another location. The probability of receiving a job offer is determined by the following equation:

$$
\operatorname{Pr}\left(j o=1 \mid e d u_{i, h}, a_{g e} e_{h, t}\right)=\Phi\left(\alpha_{0}+\sum_{i=1}^{3} \alpha_{e d u, i} e d u_{i, h}+\alpha_{3} a g e_{h, t}\right)+u_{h, t},
$$

where $\Phi$ is the cumulative standard normal distribution. If the household receives a job offer, there is a probability $\phi_{R}$ that it comes from region $R$, that is

$$
\operatorname{Pr}\left(j o_{R}=1\right)=\phi_{R} \text { for } R=1, \ldots, 9
$$

When households move, they must pay moving costs:

$$
M C=m_{0}+m_{1} \text { children } .
$$

Moving costs consist of a fixed cost $m_{0}$ and a variable cost that depends on the number of children in the household. Moving costs by number of children include both the costs of moving a larger household, the search costs of looking for a new school, and other children-specific moving costs.

\subsection{Housing choices}

Each period, households decide whether to rent or own a house. If they decide to rent, the value of the rent is given exogenously by the following equation:

$$
\log \left(\text { rent }_{t}\right)=\varphi_{0}+\sum_{i=1}^{3} \varphi_{\text {rooms }, i} D_{\text {rooms }, i}+\sum_{i=2}^{9} \varphi_{R, i} \cdot R_{i}+\sum_{i=1}^{9} \varphi_{\text {trend } \cdot R, i} \cdot t \cdot R_{i},
$$

where $D_{\text {rooms }, i}$ is a dummy variable indicating the number of rooms of the house. The categories used are less than four rooms, between five and seven rooms and with more than eight rooms. The second and third terms are region fixed effects and region-specific trends. Home values are exogenous and are determined by the following equation

$$
\log \left(\text { house_value }_{t}\right)=\theta_{0}+\sum_{i=1}^{3} \theta_{\text {rooms }, i} D_{\text {rooms }, i}+\sum_{i=2}^{9} \theta_{R, i} \cdot R_{i}+\sum_{i=1}^{9} \theta_{\text {trend } \cdot R, i} \cdot t \cdot R_{i}+\xi
$$


where $\xi$ is an i.i.d. shock normally distributed with zero mean and different variances across regions.

If households decide to buy a house, I assume they choose a 30-year mortgage with a fixed interest rate $r_{M t}$. In addition, I assume that the down payment is 20 percent of the value of the house. The law of motion for the number of years remaining on the mortgage $y m_{h, t}$ evolves according to:

$$
\begin{aligned}
y m_{h, t+1} & =30 & & \text { if the household buys a house in } t+1 \\
& =y m_{h, t}-1 & & \text { if the household keeps the house in } t \text { and } t+1 \text { and } y m_{h, t}>0 \\
& =0 & & \text { if the household keeps the house and the mortgage is fully paid } \\
& =0 & & \text { if the household rents in } t+1
\end{aligned}
$$

The number of rooms, the year and the location determine the value of the house according to equation (8). This value, the value of the downpayment, and the years remaining on the mortgage together determine the home equity on the house. Annual mortgage payments are determined by a standard mortgage formula. A feature of this formula is that home equity is accumulated more rapidly during the last years of the mortgage. If households are already homeowners, they decide whether to keep the house or to sell it. If they sell the house, they receive the home equity value. If they keep the house, they must make a mortgage payment (if they still owe money).

Households must pay transaction costs when they buy $\left(q_{b}\right)$ or sell $\left(q_{s}\right)$ a house. Transaction costs are a fraction of the value of the house. These costs include search costs as well as legal and administrative costs. Quigley (2002) reports that most estimates of legal and administrative costs are between 3 percent to 12 percent of the value of the house.

In the model, households must pay income and property taxes, and they can deduct mortgage interest and property tax payments from income taxes. Households will use the standard deduction if its value is larger than the sum of mortgage interest and property tax payments.

\subsection{Family Size}

I assume that the number of children is exogenous and evolves according to the following equation:

$$
\text { children }_{h, t+1}=\psi_{0}+\psi_{1} \text { children }_{h, t}+\psi_{2} \operatorname{age}_{h, t}+\sum_{i=1}^{3} \psi_{e d u, i} e d u_{h, i}
$$

That is, the number of children in the future depends on the current number of children, the age of the household head and the level of education of the couple. 


\subsection{Interest Rates}

Households can save and borrow to smooth consumption. If they are homeowners, they have a home equity line of credit. That is, they can borrow money to smooth consumption at an interest rate lower than that of renters. Specifically,

$$
r_{\text {sav }}<r_{h e}<r_{b},
$$

where $r_{s a v}$ is the savings interest rate, $r_{h e}$ is the home equity line of credit interest rate and $r_{b}$ is the borrowing interest rate for renters.

\subsection{Budget Constraint}

The budget constraint is summarized in the following table:

\begin{tabular}{ll}
\hline \hline Resources & Expenditures \\
\hline Labor Income & Consumption \\
Home Equity & Down payment (if household buys a house) \\
Net Wealth $r$ & Mortgage Payment (if household owns a house) \\
& Property Taxes (if household owns a house) \\
& Rent (if household rents) \\
& Moving Costs (if household moves) \\
& Transaction Costs (if household sells or buys a house) \\
& Income Taxes. \\
\end{tabular}

The difference between expenditures and resources determines net wealth in the next period.

\subsection{State Space}

Initial conditions of households are: current location, location of birth, type, net wealth, education, homeownership status, years remaining on the mortgage, number of rooms, number of children and total labor income.

At the beginning of each period, the household's state space $\Omega_{h, t}$ includes: location $\left(R_{h, t}\right)$, location of birth $\left(R_{B L h, t}\right)$, type $(b)$, net wealth $\left(W_{h, t}\right)$, education $\left(e d u_{h, t}\right)$, homeownership status $\left(H_{h, t}\right)$, years 
remaining on the mortgage $\left(y m_{h, t}\right)$, number of rooms $\left(\right.$ room $\left._{h, t}\right)$, survey year $\left(s_{h, t}\right)$, number of children $\left(\right.$ children $\left._{h, t}\right)$, income shocks $\left(\varepsilon_{h, t-1,} v_{h, t}\right)$, home values shocks $\left(\xi_{h, t}\right)$ and job offers $\left(j o, j o_{R}, j o_{R_{0}}\right)$. These variables can be classified in three groups according to their law of motion. The first group includes variables that evolve deterministically such as location of birth, type, education, number of children and survey year. The second includes variables determined by decisions made by individuals in period $t$ such as the value of assets, homeownership status, years remaining on the mortgage, house size, and location in period $t+1$. The third group includes variables that are random draws, such as job offers, and income and housing shocks.

\section{Model Solution}

The problem can be solved recursively, starting from age 65, when individuals choose consumption, house size, whether to rent or own and whether to move or not:

$$
V\left(\Omega_{h, t}\right)=\max _{c, \text { rooms }, R, \text { own }} u\left(c, \text { rooms }, R_{B L}\right)+\beta \overline{V_{t+1}}\left(\Omega_{h, t}\right),
$$

where $\overline{V_{T+1}}$ is the terminal value function. I allow for a bequest motive where a household values leaving housing equity and other assets to its heirs. In particular,

$$
\overline{V_{t+1}}\left(\Omega_{h, t}\right)=\gamma_{B} u\left(\text { home_equity }_{t}+\text { savings }_{t}, \text { rooms }, R_{B L}\right) .
$$

The parameter $\gamma_{B}$ describes a household's preference to leave a bequest. From periods 1 to T-1 individuals maximize:

$$
V\left(\Omega_{h, t}\right)=\max _{c, \text { rooms }, R, \text { own }} u\left(c_{t}, \text { rooms }_{t}, R_{B L}\right)+\beta E\left[V\left(\Omega_{h, t+1}\right) \mid \Omega_{h, t}\right]
$$

The large state space makes it infeasible to compute the value function for each possible state, because the estimation procedure requires solving the model repeatedly. Hence, instead of finding the maximum level of utility at each point of the state space, I do so for a selected subset of the state space. In particular, I use equally-spaced grid points to reduce the dimensionality of the following continuous and categorical values: survey year $\left(s_{h, t}\right)$, years paying mortgage $\left(y m_{h, t}\right)$, net wealth $\left(W_{h, t}\right)$ and lagged income shock $\left(\varepsilon_{h, t-1}\right)$. Net wealth is described using a 5-point grid between - $\$ 8,000$ 
and $\$ 88,000$. This range reflects the distribution of total wealth in the PSID. To obtain the value function at other state space points I use the interpolation method proposed by Keane and Wolpin (1994). This interpolation is used within each location, type of household, homeownership status, house size and education level. In other words, the value function is approximated over net wealth, survey year, years paying mortgage, lagged income shock and number of children. The distribution of income shocks is approximated using the method proposed in Kennan (2004) with 3 grid points.

\section{Estimation}

The estimation approach consists of two steps. In the first step, I estimate certain parameters outside the model. These are the parameters of the hedonic equations, fertility process, interest rates and share of offers coming from each region. In the second step, I estimate the remaining structural parameters using a set of moments from the PSID. These parameters include preferences, labor income process, job offers equation, and moving and transaction costs parameters.

I estimate the model using the PSID from 1984 to 1997. I use 1984 as the initial year because it is the earliest year for which the PSID contains information on assets. I keep households with married couples because divorce and widowhood are associated with housing choices. In the initial year, the estimation sample consists of household heads aged 25 to 35 years. As a result, I use 571 households in the estimation, which gives a total of 6,935 observations.

\subsection{Parameters Estimated Outside the Model}

In this section I discuss the parameters that are estimated outside the model, that is, separately from the rest of the structural parameters.

I assume that the hedonic equations (7) and (8) are exogenous and I estimate their parameters using several data sources. I estimate equation (8) using OLS and the self-reported home values from the PSID sample used in the model. I estimate the standard deviation of the home price shock $\xi$ for each region using residuals from the OLS regression. I estimate parameters $\varphi_{0}, \varphi_{\text {rooms }, i}, \varphi_{R, i}$ of equation (7) by estimating equation (7) excluding the last term (the trends) using OLS and PSID data for the years 1984 and 1985. I assume that the parameters $\varphi_{\text {trend.R, } i}$ and $\theta_{\text {trend.R, }, i}$ capture the average trends in home values and rents between the years 1984 and 1997. For instance, households predict home values in 2000 using the average trend from 1984 to 1997. As mentioned above, I estimate home 
values trends using self reported home prices from the PSID. ${ }^{13}$ Because the number of renters in the sample is relatively small, I estimate trends in rent values using the item "rent of primary residence" from the CPI, which is available for Northeast, Midwest, South and West regions. Table 4 presents estimates of equations (7) and (8). Because individuals are forward looking in the model, there is no obvious way of modeling trends in home values and rents. Any assumption about household's expectations of future home values will probably have an impact on the estimation of the structural parameters and on policy experiments. As a result, the strategy of this paper is to assume a baseline process for home values and rents trends, estimate the full model and then perform a robustness check on how sensitive the results are to different assumptions on household's expectations regarding future home values and rents. ${ }^{14}$

The number of children is exogenous and evolves according to equation (9), which is estimated using PSID data. Table 5 shows the results. All the variables are significant and the predictive power is strong, as the R-squared is equal to 0.89 .

If the household receives a job offer from another region, there is a probability $\phi_{R}$ that it comes from region $R$, where $\sum_{R=1}^{9} \phi_{R}=1$. I calibrate these probabilities so that simulated moves across regions are as similar as possible to observed ones. Table 6 shows the value of each parameter $\phi_{R}$; these values are very similar to the actual share of households moving to each region in the data.

I assume that interest rates are exogenous. In particular, I assume that interest rates on savings, loans and home equity loans are 1 percent, 10 percent and 9 percent, respectively. I use the mortgage interest rate from the Monthly Interest Rate Survey Data from the FHFA which was, on average, 8.2 percent over the period. Figure 2 displays the values of this variable by year. Finally, the intratemporal discount factor $\beta$ is assumed to be 0.97 .

Property taxes are estimated by regressing property tax payments on home values and regional dummy variables (see appendix for details). I assume that married individuals file income taxes jointly and use the income tax brackets for each calendar year.

\subsection{Parameters Estimated Inside the Model}

This section discusses the estimation of the structural parameters using the Simulated Method of Moments (SMM). I use the model and data from the initial year to generate simulated data sets by

\footnotetext{
${ }^{13}$ The regional trends estimated using this dataset are very similar to the regional trends of the House Price Index from the Federal Housing Finance Agency (FHFA).

${ }^{14}$ This robustness check is not included in this version of the paper.
} 
simulating each household 96 times. These data sets are used to compute moments which are then compared to the actual moments. The algorithm searches for parameters that minimize a weighed sum of the distances between both sets of moments. I use the inverse of the covariance matrix of data moments as a weight matrix. Table 7 lists the moments used in the estimation and Tables 8 through 11 show the parameter estimates. I compute asymptotic standard errors following Berndt, Hall, and Hall (1974) and Nash (1990).

Even though all the data moments affect the identification of every parameter, some data moments contribute more than others to the identification of a given parameter. The following paragraphs offer some intuition about how some parameters are identified from the data. Figure 3 show how some moments change when a given parameter moves away from its estimated value, holding all other parameters fixed. For instance, Figure 3 (a) shows the relationship between the housing expenditure share parameter $(a)$ and the average number of rooms per capita. The dashed vertical line shows the estimated value of parameter $a$, and the horizontal dashed line shows the average number of rooms per capita in the data. The solid line shows the average number of rooms per capita predicted by the model for different values of $a$. The solid line crosses the horizontal dashed line when $a$ is equal to its point estimate, that is, the simulated moment matches its data counterpart at the point estimate of $a$. This figure suggests that this moment in particular plays an important role in the identification of $a$.

Utility parameters $\left(a, \sigma, \eta, \kappa, b_{h}\right)$ : As seen in Table 8 , the coefficient of risk aversion is estimated to be 2.79 , which is within the range viewed as plausible in the literature. The parameter of intratemporal elasticity of substitution between housing and non-housing consumption $(\eta)$ is estimated to be 0.54 . This value is consistent with the estimate reported in Li, Liu, and Yao (2009), which uses a utility function very similar to the one in this paper. In addition, this figure is close to reducedform estimates of the elasticity of substitution between housing and non-housing consumption. ${ }^{15}$ This parameter affects the responsiveness of housing consumption to variation in relative prices. The lower the elasticity of substitution, the more quickly households adjust their housing consumption to the optimal level. The parameters $\kappa$ and $b_{h}$ are positive, which implies that there is a utility premium from owning a home and living in the household head's region of birth.

The share parameter $(a)$ is 0.0000737 . This number is difficult to interpret given that household consumption and housing services are measured in different units. However, as seen in Figure 3(a), the point estimate of this parameter helps to match the average number of rooms per capita in the

\footnotetext{
${ }^{15}$ See, for instance, Hanushek and Quigley (1980).
} 
data. Figure 3(b) shows that $\kappa$ is affected by the homeownership rate moment. Figure 3(c) shows that $\sigma$ is mostly determined by matching rooms per capita growth. The unobserved heterogeneity parameter $b_{h}$ is driven by the different propensities to move by whether the household head resides in his region of birth or not (Figure 3(j)).

Job Offers Equation $\left(\alpha_{0}, \alpha_{e d u, i}, \alpha_{3}\right)$ : The estimated parameters imply that the probability of receiving a job offer from another location is increasing in the education of the couple and decreasing in the age of the head. Figures 3(d) and 3(f) show that these parameters are largely determined by the mobility rates by education and age.

Transaction and Moving Costs $\left(q_{b}, q_{s}, m_{0}, m_{1}\right)$ : The transaction costs of selling and buying a house are estimated to be 17 percent and 10 percent of the value of the house, respectively. These numbers are higher than the typical 5-6 percent commission charged by a realtor for selling a house because they also take into account search costs, mortgage closing costs and possible psychological costs (Li, Liu, and Yao (2009)). Transaction costs $\left(q_{b}, q_{s}\right)$ are mostly identified by the average number of times a household buys a house and the probability of selling a house (see Figures 3(h) and 3(i)).

The fixed moving cost is estimated to be $\$ 2,613$ and the additional moving cost per child is estimated to be $\$ 2,582$ (in 1984 dollars). If we add the transaction costs, there is large difference between the estimates in this paper and in Gemici (2007). In particular, I estimate that the average moving cost of a family with two children who owns a home and buys another one is $\$ 36,000$. In contrast, Gemici (2007) estimates that the cost of moving for a person who is currently working, with children, and who has been in his current location for 5 years is $\$ 10,922$ (in 1983 dollars). The difference could be explained by the fact that by introducing housing choices, owning a home is a profitable investment and there are incentives to move in order to make such an investment. For instance, the difference in housing wealth gains from owning a house with four rooms for 30 years in the South West Central division and owning the same house for 30 years in the Pacific division is, on average, $\$ 97,472$. Hence, the larger present value gains from moving in this paper could explain the higher moving cost estimates. The identification of moving cost parameters is shown in Figure 3(e) and 3(g): the fixed moving cost $m_{0}$ is mostly determined by mobility moments while $m_{1}$ is mostly driven by mobility rates by number of children.

Income Process: Figure 3(k) shows that the income premium of households whose head and spouse are college graduates is mainly identified through their average labor income. There is a similar explanation for the regional and age premium parameters. The variance of the regional income shock is mostly determined by regional income variances (Figure 3(l)). The persistence in the error 
term is mainly determined by the serial correlation in labor income.

\subsection{Model Fit}

In general, the model is able to match most data moments reasonably well. Table 12 shows the moments related to the moving rates for the data and simulations. Households with more children, older heads and who own their homes tend to move less; the model generates the same result. The number of moves by education level is very similar in the model and in the data. Finally, both the data and the model show that household heads who lived in their region of birth in 1984 will move on average less times over the period than those who lived outside their region of birth in 1984 .

Table 13 shows the moments related to housing choices. The probability of selling a house, conditional on owning one, and the number of times a household buys a house are very similar in both the data and the model. The average number of rooms per capita and the average growth in rooms per capita over time are also captured well by the model. Finally, homeownership rates are slightly lower among households whose head and spouse are high school graduates.

Figure 4 shows that the model is able to fit the labor income profiles of households by their location, education and age of the head. In addition, the income variance in each region are very similar in both the model and the data. The serial correlation of labor income is 0.81 in the data and 0.79 in the model.

Figure 5 (a) shows that the distribution of total labor income is, in general, well approximated by the model, although its variance is higher than in the data. Figure 5 (b) shows that the model is able to capture the concave shape of the homeownership-age profile in the data. Figures 5 (c), (d) and (e) show that the evolution of the average ratio of home values and rents to income, and rooms per capita is well captured by the model. One area where the model fails to fully account for the data is in predicting the level of non-housing assets (see Figure 5 (f)). This could be explained by the fact that in the model households can only invest on housing and savings, that is, households can not make other non-housing investments with a higher return. As a result, the interest rate on savings might be too low to encourage savings in the model.

Table 14 contains the average number of children, labor income and labor income growth by homeownership status; it shows that in both the simulations and the data homeowners have more children, higher incomes and lower income growth. However, the model predicts that renters have a higher wage growth than in the data. 
Table 15 displays the share of households moving to and from each region. In general, the model matches these regional migration patterns well.

\section{Does Owning a Home Affect the Response to Labor Market Shocks?}

This section shows that homeownership affects households' migration decisions and labor income. I begin by showing that the model replicates the differences-in-differences estimates from section 3.2. I then estimate the differences-in-differences effect using a control group generated by the model.

Tables 16 through 18 present estimates of the following differences-in-differences model:

$$
\begin{aligned}
Y_{i, t}= & \beta_{0}+\beta_{1, t_{0}} \operatorname{shock}_{i, t=t_{0}}+\beta_{1, t \geq t_{0+1}} \operatorname{shock}_{i, t \geq t_{0}+1}+ \\
& +\beta_{2, t_{0}} \text { shock }_{i, t=t_{0}} \cdot h_{i, t_{0}}+\beta_{2, t \geq t_{0}+1} \operatorname{shock}_{i, t \geq t_{0+1}} \cdot h_{i, t_{0}}+ \\
& +\beta_{3} h_{i, t}+\Gamma X+\varepsilon_{i, t},
\end{aligned}
$$

where

$h_{i, t}:$ Indicates whether the household is in the treatment $(=1)$ or control $(=0)$ group shock $_{i, t}$ : Indicates whether the household received $(=1)$ the labor market shock or not $(=0)$

$t_{0}:$ Indicates the time of the shock

$X_{i, t} \quad$ : Vector of control variables including age of the head, education of the couple and number of children.

While the parameters $\beta_{1, t=t_{0}}$ and $\beta_{2, t=t_{0}}$ measure the temporary effect of the shock, the parameters

$\beta_{1, t \geq t_{0+1}}$ and $\beta_{2, t \geq t_{0}+1}$ are intended to capture the permanent effect of the shock. I estimate the effect on two alternative outcomes $Y_{i, t}$ : mobility and household labor income.

Table 16 presents a robustness check of the model. The first two columns show the estimated parameters of equation (10) using the data and including renters in the control group. In the data, I define a negative labor market shock as in Section 3.2. The second column restricts the sample to households used in the estimation of the structural model. To increase the precision of the estimated parameters, the first column also includes households who enter the sample after 1984. The last column of Table 16 shows results using simulated data. In the simulations, I define a negative labor 
market shock as an income drop of at least 20 percent. Although the absolute values of parameters estimated using the data and the simulations are different, the signs of most coefficients are similar. In both the data and the model, homeowners move less than renters, renters have higher mobility rates at the time of a negative labor market shock, and the permanent effect of the shock on labor income is greater for owners than for renters. In summary, the model seems to capture these features of the data reasonably well. ${ }^{16}$

Table 17 shows the estimated parameters of equation (10) using two alternative control groups: renters and the model's counterfactual. In the counterfactual, homeowners can sell and buy a house without paying transaction costs during a labor market shock. Hence, their moving costs are similar to renters' moving costs. Columns (1) and (2) show that the estimated effect of owning a home on mobility is negative using either control group. However, using renters as the control group over-estimates the negative effect of homeownership. Using the model's counterfactual, Column (2) shows that homeownership decreases mobility by 0.5 percentage points. This is a large effect, because the average mobility rate of the sample is 1.2 percentage points. Columns (3) and (4) show that using renters as the control group over-estimates the effect of homeownership on labor income. The first row shows that labor income is, on average, 16 percent higher for homeowners than for renters; however, the causal effect of homeownership on labor income is almost zero. If anything, homeownership has a small negative effect on labor income, of around 0.1 percent. The remaining parameters show that the effect of homeownership on labor income during and after a negative labor market shock is rather small, lower than 1 percent. In contrast, using renters as the control group over-estimates this effect, suggesting that owning a home during a negative labor market shock decreases average labor income permanently by an additional 6.6 percent.

Table 18 reports the effect of homeownership on the probability of moving in response to a better job offer. Specifically, I estimate equation (10) and define shock as a job offer from another location that implies an income increase of at least 20 percent. Column (1) shows that homeowners are 22 percent less likely than renters to take a better job in another region. Nevertheless, the effect of homeownership is considerably smaller when using the model's counterfactual as the control group: owning a home decreases the probability of moving in response to a job offer by only 5 percent. Columns (3) and (4) report the effect of the labor market shock on labor income. Owners' labor income increases 6.6 percent less than renters' at the time of the shock, and 5 percent less than renters'

\footnotetext{
${ }^{16}$ According to column (5), homeowners' labor income decreases less than renters' at the time of the shock. However, this result is probably due to the low number of individuals who receive a negative shock in the model's sample. As seen in column (4), using a larger sample shows that homeowners' labor income decreases more than renters' during the shock.
} 
after the shock. However, column (4) shows that the actual effect of homeownership is much smaller: owning a home reduces labor income by 2.2 percent at the time of the shock, and by 1 percent after the shock.

The results from this section suggest that using renters as the control group introduces a negative bias on estimates of the effect of homeownership on mobility and labor income. The main reason for this result is that the model's counterfactual controls for expected mobility; that is, individuals are more likely to buy a house when they expect to move less in the near future. Hence, even when they do not have to pay transaction costs during a labor market shock, homeowners are less likely to move than renters. This may be because they are less likely to receive a job offer, less likely to be a mover-type, more likely to live in their home location or because they have more children (see Table 19).

\section{The Effect of Income Shocks During a Housing Bust}

In this section, I estimate the effects of negative income and home price shocks on mobility and labor income. During the recent housing bust, many households experienced large and simultaneous falls in home values and income. As a result, millions of homeowners owing more on their mortgages than current market value found themselves "underwater". Ferreira, Gyourko, and Tracy (2008) find that household mobility decreases during a housing bust. In particular, the authors find that owners suffering from negative equity are one-third less mobile and claim that this is likely to result in more inefficient matching in the labor market. In this section I estimate the effect of negative home price shocks on mobility and labor income. Even though a decrease in home prices does not necessarily translate into negative equity, the price shock in the model would affect mobility by the same mechanisms as in Ferreira, Gyourko, and Tracy (2008). Specifically, the shock would make households more liquidity constrained to afford a move. In addition, households who are not financially constrained and expect home prices to increase might be less likely to sell their homes and move because it is optimal for them to sell in the future.

Table 20 shows estimates of the following equation:

$$
\begin{aligned}
Y_{i, t}= & \beta_{0}+\beta_{1, t_{0}} \text { shock }_{i, t=t_{0}}^{y}+\beta_{1, t \geq t_{0+1}} \text { shock }_{i, t \geq t_{0}+1}^{y} \\
& +\beta_{2, t_{0}} \text { shock }_{i, t=t_{0}}^{h}+\beta_{2, t \geq t_{0}+1} \text { shock }_{i, t \geq t_{0+1}}^{h} \\
& +\beta_{3, t_{0}} \text { shock }_{i, t=t_{0}}^{y h}+\beta_{3, t \geq t_{0}+1} \text { shock }_{i, t \geq t_{0+1}}^{y h} \\
& +\beta_{4} \text { home_owner }_{i, t}+\varepsilon_{i, t},
\end{aligned}
$$


where $s h o c k^{y}$ and $s h o c k^{h}$ are dummy variables equal to one if a household experiences a decrease of at least 10 percent in labor income or a decrease of at least 10 percent in the value of its home, respectively; shock $k^{y h}$ is a dummy variable equal to one if the household experiences both shocks at the same time. I estimate this equation restricting the sample to households who are homeowners at the time of receiving the shocks and to households who are homeowners but did not receive the shock. The first column of Table 20 shows that households are less likely to move when facing a decrease in their home value. The magnitude of the effect is relatively large, and implies that the probability of moving would decrease from 1.3 percent to 0.8 percent. As previously discussed, negative income shocks have a positive effect on the probability of moving. However, the interaction term between income and housing shocks is not significant. The second column shows that households who face a decrease in the value of their property do not experience a change in labor income. However, one of the interaction terms is significant; that is, housing shocks exacerbate the effects of income shocks since the labor income of households experiencing both shocks decreases permanently by an aditional 3\%.

In summary, the results from this section are consistent with the findings of Ferreira, Gyourko, and Tracy (2008). While they find that having negative equity decreases mobility, I find that a decrease in home equity makes households less likely to move. In addition, negative housing shocks seem to exacerbate the effect of negative income shocks, that is, households who face both shocks simultaneously experience a larger fall in labor income than those who only experience income shocks.

\section{Policy Experiments}

In this section, I perform two policy experiments. First, I estimate the effect of eliminating the home mortgage interest deduction on mobility, homeownership and labor income. Second, I estimate the effect of eliminating the 20 percent down payment requirement to buy a house on the same set of outcomes. A limitation of these policy experiments is that they do not consider general equilibrium effects that might affect final outcomes. However, they do show what would be the first response of households if they faced a new set of incentives. 


\subsection{Eliminating the Mortgage Interest Tax Deduction}

In 2009, the federal government lost $\$ 97$ billion in tax revenue to the home mortgage interest deduction. ${ }^{17}$ This deduction stands as one of the most debated features of the U.S. tax code (Glaeser and Shapiro (2003)).

The home mortgage deduction disproportionately benefits the wealthy because most of the deductions are claimed by this group (Prante (2006)). There are several reasons for this distribution of the subsidy. First, because of the progressive nature of the federal income tax, the value of the deduction rises with income. As a result, low-income taxpayers have fewer incentives to itemize deductions. Second, low-income individuals are less likely to own a home. Finally, wealthier individuals tend to own more expensive homes. In general, this implies a greater interest payment on the associated mortgage. Supporters of the home mortgage deduction claim that homeownership has externalities that might be worth subsidizing.

To my knowledge, few papers have tried to estimate the effect of the home mortgage deduction on homeownership using microdata. For instance, using data from the PSID, Sinai (1997) claims that the deduction has a significant effect on homeownership and mobility. Using time-series data, Rosen and Rosen (1980) and Glaeser and Shapiro (2003) find opposite results: while the former suggest a sizable effect of the deduction on homeownership, the latter suggests that the deduction has no effect on homeownership rates. In this section, I measure the effect of the home mortgage deduction on homeownership. In addition, I investigate whether this subsidy affects housing consumption, mobility and labor income. It is important to keep in mind that the sample used in this paper does not include non-whites and high school dropouts, that is, it only includes households who are more likely to be affected by this policy experiment.

Table 21 shows the change in housing choices by income quintiles if households were not allowed to deduct mortgage interest payments from their income taxes. Two factors affect the different effects of the policy change across income quintiles. First, as the tax incentive increases with income (see column (2)), wealthier households might be more likely to respond to the policy change by adjusting their housing consumption. Second, and in contrast to the previous effect, wealthier households are less liquidity constrained and therefore more likely to buy a house regardless of the size of the deduction. The results in column (3) suggest that the second effect is more important, as it shows that the homeownership rate decreases more for low-income households and it does not change for households in the fifth quintile. Column (4) shows that richer households respond to the policy

\footnotetext{
${ }^{17}$ Budget of the U.S. Government, Fiscal year 2010, Office of Management and Budget.
} 
change by adjusting house size. For instance, if the deduction were eliminated households in the fifth quintile would live in homes with 0.5 less rooms. In contrast, low-income households do not significantly change their house size in response to the policy change.

Columns (6) and (7) of Table 21 report the effect of the policy on mobility and labor income. The elimination of the home mortgage interest deduction might affect mobility, and therefore labor income, through two channels. First, by decreasing homeownership rates and house size, the policy change reduces moving costs and thereby makes households more likely to move. Second, if households tend to move to make a housing investment, the elimination of the deduction increases the moving costs of households who plan to move and buy a home. Column (5) shows that richer households are more likely to buy a house right after they move: while only 17 percent of households in the first quintile buy a home after they move, that figure increases to 69 percent for households in the fifth quintile. Column (6) shows that low-income households would be more likely to move if the deduction were eliminated, suggesting that the first mechanism might be more important for them. In contrast, households in the fifth quintile would be less likely to move if the deduction were eliminated, suggesting that their mobility choices are more affected by housing investment opportunities. These changes in mobility translate into changes in labor income: while the labor income of households in the first quintile increases $0.7 \%$ under the counterfactual, households in the richest quintile witness a decrease in their labor income of $1.26 \%$.

\subsection{Eliminating Liquidity Constraints: Zero Downpayment}

Government efforts to increase homeownership have often focused on generating greater and more widespread access to credit markets (Vigdor (2006)). In fact, the relaxation of liquidity constraints has been associated with increases in homeownership rates. For instance, Fetter (2010) finds that the VA program, which provided a number of benefits for veterans to buy a home, including an elimination of down payment requirements, can explain approximately 10 percent of the increase in aggregate home ownership from 1940 to 1960. During the recent housing boom, downpayment requirements significantly decreased (Geanakoplos (2010)) and homeownership rates rose. However, little is known about the potential effects of relaxing liquidity constraints on mobility and labor market outcomes. In this section, I perform a policy experiment where all the households can buy a house with zero downpayment. I then estimate the effect of this policy on homeownership rates, housing consumption, mobility and labor income.

Table 22 presents the effects of eliminating the down payment requirement by income quintiles. 
The policy change has a significant positive effect on homeownership rates for all income groups, but it is considerably stronger for low-income households, as they are more liquidity constrained than high-income households in the baseline scenario. The policy change also affects the average house size: while low-income households would live in smaller homes, wealthier households would move to larger homes. These different responses across income levels is explained by the fact that low-income househols live in larger rental units in the baseline scenario and can only afford to buy smaller houses in the counterfactual. In contrast, wealthier households would sell their homes to buy larger homes that do not require a downpayment.

Columns (4) and (5) report the effects on mobility and labor income. Low-income households would be more likely to move if they did not have to make a downpayment, as they become less liquidity constrained to make a housing investment in another location. In contrast, higher-income households would be less likely to move, as they tend to buy larger homes in their current location, thereby increasing their moving costs. Column (5) shows that these changes in mobility rates translate into average labor income.

Columns (6) and (7) restrict the sample to households who change their homeownership status in response to the policy change and experience an income drop of at least 20 percent. All households would be less likely to move under the counterfactual. The effect is smaller among low-income households since their mobility rates are very low in the baseline. In contrast, high-income households would be considerably less likely to move under the counterfactual, and would witness a larger drop in labor income than lower-income households.

\section{Conclusion}

The main hypothesis of this paper is that transaction costs in the housing market affect migration decisions and labor market outcomes. To identify this effect, I develop and estimate a structural dynamic model of housing choices, migration decisions and labor market outcomes.

Using a reduced-form framework, I start by documenting the fact that renters are more likely to move than homeowners during a negative labor market shock. In addition, negative labor market shocks seem to have a permanent effect on homeowners' labor market outcomes, but the effects are transitory for renters'. I also show that renters are different from homeowners along several socioeconomic outcomes. Therefore, they are not a good control group for homeowners. I use the model to generate a control group for homeowners and find that homeownership has a large negative effect 
on mobility. Homeownership also has a small negative effect on labor income. Both effects are larger in absolute value when using renters as the control group; that is, using renters as the comparison group for homeowners introduces a negative bias on the estimates. I also find that owners suffering from a decrease in home equity are less likely to move to another location.

I use the model to conduct two policy experiments. First, I assess the effect of the home mortgage deduction. Opponents of this tax incentive claim that since it only benefits the wealthy, it does not increase homeownership and only increases the incentive to buy larger houses. I find that the home mortgage deduction has a large effect on homeownership among low-income households and that it introduces an incentive to buy larger houses among all households. At the same time, the deduction reduces mobility and labor income among low-income households and has the opposite effects among high-income households. However, it is important to keep in mind that the sample used in this paper does not include non-whites and high school dropouts, that is, it only includes households who are more likely to be affected by this policy experiment.

In the second policy experiment I find that if the downpayment requirement to buy a home is eliminated, homeownership rates experience a large increase. In addition, the mobility rate of lowincome households increases, as they become less liquidity constrained to afford a move. In contrast, the mobility rate of higher-income households decreases, as they buy larger homes in their current location, thereby increasing their moving costs. In addition, the average mobility and labor income decreases among all households experiencing negative labor market shocks.

This paper makes three main contributions. First, to my knowledge, this is the first paper to develop and estimate a structural dynamic model of location, housing and labor market outcomes. Second, while the main hypothesis of this paper has been previously evaluated in the literature, existing papers have limitations. In particular, while some of them defined renters as the control group for homeowners, others have used aggregate data. In this paper I argue that both approaches are misleading because renters are not comparable to homeowners and aggregate data studies are usually affected by omitted variable and measurement error biases. By explicitly modeling housing and migration choices the results of this paper control for omitted variables and reverse causality issues that affect existing empirical evidence. Third, this is the first paper that estimates the effect of the home mortgage tax deduction and of liquidity constraints on housing choices, mobility decisions and labor market outcomes.

The results of this paper suggest that policies that promote homeownership must weigh the negative effects that homeownership has on mobility and labor income against the positive externalities 
that it might generate.

A limitation of the analysis in this paper is that marriage and fertility decisions are not taken into account. Marriage, fertility and housing choices are likely to be related because buying a home is one of the most important investments made by individuals over the life-cycle. A direction for future research is studying the migration and housing choices of agents jointly with their marriage and fertility decisions. 


\section{References}

Alba, R., J. LOGAN, AND P. Bellair (1994): “Living with crime: The implications of racial/ethnic differences in suburban location," Social Forces, 73(2), 395-434.

Bajari, P., P. Chan, D. KRueger, And D. Miller (2009): “A Dynamic Structural Model of Housing Demand: Estimation and Policy Implications," University of Pennsylvania.

BERNDT, E., B. HALL, AND R. HALL (1974): “Estimation and inference in nonlinear structural models," NBER Chapters, pp. 103-116.

BlAnCHARD, O., AND L. KATZ (1992): “Regional evolutions,” Brookings Papers on Economic Activity: 1, Macroeconomics, p. 1.

COUlsON, N., AND L. FISHER (2002): “Tenure choice and labour market outcomes," Housing Studies, 17(1), 35-49.

(2009): "Housing tenure and labor market impacts: The search goes on," Journal of Urban Economics, 65(3), 252-264.

DiETZ, R., AND D. HAURIN (2003): “The social and private micro-level consequences of homeownership," Journal of Urban Economics, 54(3), 401-450.

DiPasquale, D., And E. Glaeser (1999): “Incentives and Social Capital: Are Homeowners Better Citizens?," Journal of Urban Economics, 45(2), 354-384.

Ferreira, F., J. Gyourko, And J. Tracy (2008): “Housing Busts and Household Mobility,” NBER Working Paper.

FetTeR, D. (2010): “Housing Finance and the mid-century transformation in US home ownership: the VA home loan program," Working Paper.

Geanakoplos, J. (2010): "Solving the Present Crisis and Managing the Leverage Cycle," FRBNY Economic Policy Review.

GEMICI, A. (2007): “Family migration and labor market outcomes," University of Pennsylvania.

Glaeser, E., AND B. SACERdote (2000): “The Social Consequences of Housing," Journal of Housing Economics, 9(1-2), 1-23. 
Glaeser, E., AND J. Shapiro (2003): “The benefits of the home mortgage interest deduction," Tax policy and the economy, 17, 37-82.

Green, R., And P. Hendershott (2001): “Home-ownership and the duration of unemployment: a test of the Oswald hypothesis," NBER Working paper.

Green, R., And M. White (1997): "Measuring the Benefits of Homeowning: Effects on Children* 1," Journal of Urban Economics, 41(3), 441-461.

HanUsheK, E., AND J. Quigley (1980): “What is the price elasticity of housing demand?," The Review of Economics and Statistics, 62(3), 449-454.

Haurin, D., T. PARCEL, AND R. HAURin (2002): “Does homeownership affect child outcomes?," Real Estate Economics, 30(4), 635-667.

KAPLAN, G. (2009): “Moving back home: Insurance against labor market risk,” Job Market Paper, New York University, Department of Economics.

KEANE, M., AND K. WOLPIN (1994): “The solution and estimation of discrete choice dynamic programming models by simulation and interpolation: Monte Carlo evidence," The Review of Economics and Statistics, pp. 648-672.

KennAN, J. (2004): “A Note on Approximating Distribution Functions," University of WisconsinMadison.

KENNAN, J., AND J. WALKER (2003): “The effect of expected income on individual migration decisions," .

KIYOTAKI, N., AND K. NiKOlOV (2008): “Winners and Losers in Housing Markets!,” .

KRUEger, A., AND L. Summers (1988): “Efficiency wages and the inter-industry wage structure," Econometrica: Journal of the Econometric Society, 56(2), 259-293.

LI, W., H. LIU, AND R. YAO (2009): “Housing over Time and over the Life Cycle: A Structural Estimation," .

Macintyre, S., A. Ellaway, G. Der, G. Ford, and K. Hunt (1998): “Do housing tenure and car access predict health because they are simply markers of income or self esteem? A Scottish study," British Medical Journal, 52(10), 657. 
Munch, J., M. Rosholm, And M. Svarer (2008): “Home ownership, job duration, and wages," Journal of Urban Economics, 63(1), 130-145.

NASH, J. (1990): Compact numerical methods for computers: linear algebra and function minimisation. Taylor \& Francis.

OsWALD, A. (1996): A conjecture on the explanation for high unemployment in the industrialised nations: Part 1. University of Warwick, Department of Economics.

Prante, G. (2006): “Who Benefits from the Home Mortgage Interest Deduction?," Fiscal Facts, Tax Foundation.

Quigley, J. (2002): “Transactions Costs and Housing Markets," .

Rosen, H., And K. Rosen (1980): “Federal taxes and homeownership: Evidence from time series," The Journal of Political Economy, 88(1), 59-75.

SHIMer, R. (2007): “Mismatch,” The American Economic Review, 97(4), 1074-1101.

SINAI, T. (1997): “Taxation, User Cost and Household Mobility Decisions," Zell/Lurie Center Working Paper, 303.

VAn Leuvensteijn, M., AND P. KOning (2004): “The effect of home-ownership on labor mobility in the Netherlands," Journal of Urban Economics, 55(3), 580-596.

VIGDOR, J. (2006): “Liquidity constraints and housing prices: Theory and evidence from the VA Mortgage Program," Journal of Public Economics, 90(8-9), 1579-1600. 
Table 1: Descriptive Statistics by Homeownership Status

\begin{tabular}{|c|c|c|c|}
\hline & Renters & Homeowners & Homeowners-Renters \\
\hline \multicolumn{4}{|l|}{ Head's Education } \\
\hline \multirow[t]{2}{*}{$\%$ HS Dropout } & 0.160 & 0.072 & -0.088 \\
\hline & $(0.007)$ & $(0.003)$ & $(0.010)$ \\
\hline \multirow[t]{2}{*}{$\%$ HS Graduate } & 0.616 & 0.659 & 0.042 \\
\hline & $(0.011)$ & $(0.006)$ & $(0.012)$ \\
\hline \multirow[t]{2}{*}{$\%$ College Graduate } & 0.252 & 0.278 & 0.026 \\
\hline & $(0.006)$ & $(0.006)$ & $(0.008)$ \\
\hline \multicolumn{4}{|l|}{ Spouse's Education } \\
\hline \multirow[t]{2}{*}{ \% HS Dropout } & 0.122 & 0.068 & -0.054 \\
\hline & $(0.008)$ & $(0.003)$ & $(0.006)$ \\
\hline \multirow[t]{2}{*}{$\% \mathrm{HS}$ Graduate } & 0.675 & 0.695 & 0.020 \\
\hline & $(0.007)$ & $(0.004)$ & $(0.008)$ \\
\hline \multirow[t]{2}{*}{ \%College Graduate } & 0.206 & 0.239 & 0.033 \\
\hline & $(0.008)$ & $(0.005)$ & $(0.007)$ \\
\hline \multirow[t]{2}{*}{ Head's age } & 29.5 & 31.0 & 1.6 \\
\hline & $(0.038)$ & $(0.049)$ & $(0.051)$ \\
\hline \multirow{2}{*}{ Head's Labor Income } & 18854.7 & 25878.7 & 7024.0 \\
\hline & $(117.9)$ & $(152.1)$ & $(133.8)$ \\
\hline \multirow[t]{2}{*}{ Family Labor Income } & 26163.2 & 35025.6 & 8862.4 \\
\hline & $(205.1)$ & $(234.8)$ & $(318.6)$ \\
\hline \multirow[t]{2}{*}{ Labor Income per capita } & 9611.7 & 11634.8 & 2023.1 \\
\hline & $(94.3)$ & $(102.0)$ & (186.1) \\
\hline \multirow[t]{2}{*}{ Net Savings } & 4470.2 & 9433.5 & 4963.2 \\
\hline & $(1821.1)$ & $(1139.0)$ & $(1301.8)$ \\
\hline \multirow[t]{2}{*}{ Rooms } & 5.0 & 6.3 & 1.2 \\
\hline & $(0.012)$ & $(0.021)$ & $(0.032)$ \\
\hline \multirow[t]{2}{*}{ Rooms per capita } & 1.7 & 2.0 & 0.3 \\
\hline & $(0.012)$ & $(0.008)$ & $(0.015)$ \\
\hline \multirow[t]{2}{*}{ Number of children } & 1.2 & 1.4 & 0.3 \\
\hline & $(0.018)$ & $(0.017)$ & $(0.021)$ \\
\hline \multirow[t]{2}{*}{$\%$ Change job } & 0.366 & 0.196 & -0.170 \\
\hline & $(0.008)$ & $(0.003)$ & $(0.008)$ \\
\hline \multirow[t]{2}{*}{$\%$ Unemployed } & 0.076 & 0.030 & -0.047 \\
\hline & $(0.002)$ & $(0.001)$ & $(0.006)$ \\
\hline \multicolumn{4}{|l|}{ Mobility Rates } \\
\hline \multirow[t]{2}{*}{ All moves } & 0.445 & 0.111 & -0.333 \\
\hline & $(0.010)$ & $(0.004)$ & $(0.009)$ \\
\hline \multirow{2}{*}{ Inter-State moves } & 0.082 & 0.024 & -0.058 \\
\hline & $(0.007)$ & $(0.001)$ & $(0.005)$ \\
\hline \multirow[t]{2}{*}{ Inter-Census Region moves } & 0.057 & 0.017 & -0.039 \\
\hline & $(0.003)$ & $(0.001)$ & $(0.005)$ \\
\hline$N$ & 3331 & 6303 & 9634 \\
\hline
\end{tabular}

Own estimates from the PSID 1980-1997. Sample includes married households whose head is white, male and ages 25 to 55. Bootstrapped standard errors in parentheses. The first and second columns show sample means for renters and homeowners, respectively. The third column shows the d3ifference in means between renters and homeowners for the corresponding variable. 
Table 2: Negative Labor Market Shocks, by Homeownership Status

\begin{tabular}{|c|c|c|c|c|c|}
\hline & \multicolumn{5}{|c|}{ Dependent Variable } \\
\hline & Moved & $\begin{array}{c}\text { Moved across } \\
\text { States } \\
\end{array}$ & $\begin{array}{c}\text { Moved Across } \\
\text { Census Divisions }\end{array}$ & Unemployed & Total Labor Income \\
\hline Owner & $\begin{array}{c}-0.356^{* * *} \\
{[0.00865]}\end{array}$ & $\begin{array}{c}-0.0369 * * * \\
{[0.00452]}\end{array}$ & $\begin{array}{c}-0.0174 * * * \\
{[0.00386]}\end{array}$ & $\begin{array}{l}-0.0122^{* *} \\
{[0.00498]}\end{array}$ & $\begin{array}{c}0.0976 * * * \\
{[0.00972]}\end{array}$ \\
\hline $\operatorname{shock}(\mathrm{t} 0)$ & $\begin{array}{c}0.0582^{* *} \\
{[0.0257]}\end{array}$ & $\begin{array}{c}0.0520 * * * \\
{[0.0133]}\end{array}$ & $\begin{array}{c}0.0416 * * * \\
{[0.0114]}\end{array}$ & $\begin{array}{l}0.267 * * * \\
{[0.0173]}\end{array}$ & $\begin{array}{c}-0.157 * * * \\
{[0.0338]}\end{array}$ \\
\hline $\operatorname{shock}(t>=t 0+1)$ & & & & $\begin{array}{l}-0.00793 \\
{[0.0135]}\end{array}$ & $\begin{array}{c}-0.107^{* * *} \\
{[0.0263]}\end{array}$ \\
\hline shock $(\mathrm{t} 0)^{*}$ owner $(\mathrm{t} 0)$ & $\begin{array}{c}-0.0413 \\
{[0.0314]}\end{array}$ & $\begin{array}{c}-0.0455 * * * \\
{[0.0163]}\end{array}$ & $\begin{array}{c}-0.0383^{* * *} \\
{[0.0139]}\end{array}$ & $\begin{array}{l}9.98 \mathrm{e}-05 \\
{[0.0207]}\end{array}$ & $\begin{array}{l}-0.0433 \\
{[0.0404]}\end{array}$ \\
\hline shock $(t>=t 0+1) *$ owner $(t 0)$ & & & & $\begin{array}{c}0.0571 * * * \\
{[0.0154]}\end{array}$ & $\begin{array}{c}-0.0668 * * \\
{[0.0301]}\end{array}$ \\
\hline Constant & $\begin{array}{c}0.519 * * * \\
{[0.0156]}\end{array}$ & $\begin{array}{l}0.0482 * * * \\
{[0.00935]}\end{array}$ & $\begin{array}{l}0.0317^{* * *} \\
{[0.00797]}\end{array}$ & $\begin{array}{l}0.0452 * * * \\
{[0.00897]}\end{array}$ & $\begin{array}{l}10.57^{* * *} \\
{[0.0212]}\end{array}$ \\
\hline Observations & 22597 & 22402 & 22402 & 22608 & 22489 \\
\hline R-squared & 0.106 & 0.008 & 0.004 & 0.046 & 0.076 \\
\hline
\end{tabular}

Own estimates from the PSID 1980-1997. Sample includes married households whose head is white, male and ages 25 to 55. Each cell reports the estimated coefficients $\beta_{k}$ from equation (1) in the text. I include dummy variables for age, education of the head and the spouse, number of children and individual fixed effects as controls. Income variables are in logs. 
Table 3: Mobility

\begin{tabular}{|c|c|c|c|}
\hline & \multicolumn{3}{|c|}{ Mobility } \\
\hline & All & Inter-State & Inter-Region \\
\hline Mobility Rates & $17.8 \%$ & $3.4 \%$ & $2.4 \%$ \\
\hline \multicolumn{4}{|c|}{ Percentage of Households by Number of Moves } \\
\hline Never Moved & $26.1 \%$ & $81.3 \%$ & $85.8 \%$ \\
\hline Moved Once & $26.0 \%$ & $10.2 \%$ & $8.5 \%$ \\
\hline Moved Twice or More & $47.9 \%$ & $8.5 \%$ & $5.7 \%$ \\
\hline \multicolumn{4}{|l|}{ Reason for Moving } \\
\hline Job-Related & $21.3 \%$ & $61.4 \%$ & $62.2 \%$ \\
\hline Housing/Neighborhood-Related & $59.6 \%$ & $21.2 \%$ & $20.5 \%$ \\
\hline Other & $19.1 \%$ & $17.4 \%$ & $17.2 \%$ \\
\hline
\end{tabular}

Own estimates from the PSID 1980-1997. Sample includes married households whose head is white, male and ages 25 to 55. Job-related moves include moves "to take another job; transfer; stopped going to school; To get nearer to work". Housing/Neighborhood-related moves include moves for "expansion/contraction of housing: more/less space; better place; less rent; other house-related: want to own home; got married; neighborhood-related: better neighborhood; go to school". Other reasons for moving include "involuntary reasons: housing unit coming down, being evicted, armed services, etc.; health reasons; divorce; retiring because of health; ambiguous or mixed reasons: to save money; all neighbors moved away; retiring." 
Table 4: Hedonic Equations

\begin{tabular}{|c|c|c|}
\hline \multicolumn{3}{|c|}{ (A) Initial year estimates } \\
\hline & In(home_value) & In(rent) \\
\hline \multirow[t]{2}{*}{ rooms $[5,7]$} & $0.700 * * *$ & $0.112^{*}$ \\
\hline & [0.108] & {$[0.0581]$} \\
\hline \multirow[t]{2}{*}{$\operatorname{rooms}[8,]}$. & $1.117^{* * *}$ & $0.270^{* * *}$ \\
\hline & {$[0.126]$} & {$[0.125]$} \\
\hline \multirow[t]{2}{*}{ Middle Atlantic } & $-0.281^{*}$ & -0.0355 \\
\hline & {$[0.154]$} & {$[0.127]$} \\
\hline \multirow[t]{2}{*}{ East North Central } & -0.162 & -0.210 \\
\hline & {$[0.152]$} & {$[0.133]$} \\
\hline \multirow[t]{2}{*}{ West North Central } & $-0.350^{* *}$ & $-0.623^{* * *}$ \\
\hline & {$[0.157]$} & {$[0.164]$} \\
\hline \multirow[t]{2}{*}{ South Atlantic } & -0.159 & -0.0577 \\
\hline & {$[0.155]$} & {$[0.141]$} \\
\hline \multirow[t]{2}{*}{ East South Central } & $-0.365^{* *}$ & -0.290 \\
\hline & {$[0.175]$} & {$[0.189]$} \\
\hline \multirow[t]{2}{*}{ West South Central } & -0.0768 & $-0.317^{* *}$ \\
\hline & {$[0.165]$} & {$[0.148]$} \\
\hline \multirow[t]{2}{*}{ Mountain } & -0.0392 & -0.105 \\
\hline & {$[0.173]$} & {$[0.163]$} \\
\hline \multirow[t]{2}{*}{ Pacific } & $0.345^{* *}$ & 0.139 \\
\hline & {$[0.161]$} & {$[0.128]$} \\
\hline \multirow[t]{2}{*}{ Constant } & $10.32^{* * *}$ & $8.228 * * *$ \\
\hline & {$[0.161]$} & {$[0.114]$} \\
\hline Observations & 393 & 296 \\
\hline R-squared & 0.238 & 0.161 \\
\hline
\end{tabular}

(B) Trends

$\begin{array}{lcc}\text { New England } & 0.0249^{* * *} & 0.0131^{* * * *} \\ \text { Middle Atlantic } & {[0.00704]} & {[0.00212]} \\ & 0.0271^{* * *} & 0.0131^{* * *} \\ \text { East North Central } & {[0.00525]} & {[0.00212]} \\ & 0.0177^{* * *} & 0.00309^{* * *} \\ \text { West North Central } & {[0.000814]} & {[0.000981]} \\ & -0.000495 & 0.00309^{* * *} \\ \text { South Atlantic } & {[0.00103]} & {[0.000981]} \\ & 0.00644^{* * *} & -0.00269^{* * *} \\ \text { East South Central } & {[0.00170]} & {[0.000760]} \\ & 0.00394^{* * *} & -0.00269^{* * *} \\ \text { West South Central } & {[0.00107]} & {[0.000760]} \\ & -0.0296^{* * *} & -0.00269^{* * *} \\ \text { Mountain } & {[0.00205]} & {[0.000760]} \\ & -0.00446^{*} & 0.00555^{* * *} \\ \text { Pacific } & {[0.00232]} & {[0.00174]} \\ & 0.0237^{* * *} & 0.00555^{* * *} \\ & {[0.00378]} & {[0.00174]} \\ & & \end{array}$

Standard errors in brackets

$* * * p<0.01, * * p<0.05, * p<0.1$

The first and second column report the estimates of equations (8) and (7) in the text. Coefficients in column (1) are estimated by OLS using the PSID 1984-1997. Coefficients in column (2) of Panel (A) are estimated by OLS using PSID 1984-1985. The sample includes married households whose head is white, male and ages 25 to 48 . Coefficients in the first column of Panel (B) are estimated using the item "rent of primary residence" from the CPI as a dependent variable from 1984 to 1997, deflated by the general CPI. I estimate an OLS equation separately for each region with the price index as the dependent variable and a linear trend as a regressor, to measure the average change in the dependent variable over the period. 
Table 5: Number of Children Equation

\begin{tabular}{lc}
\hline \hline & Number of Children \\
\cline { 2 - 2 } Number of Children (t-1) & $0.945^{* * * *}$ \\
Age & {$[0.00421]$} \\
& $-0.0186^{* * *}$ \\
Head HS grad and Spouse College grad & {$[0.000848]$} \\
& $0.0735^{* * *}$ \\
Head College grad and Spouse HS grad & {$[0.0156]$} \\
& $0.0459^{* * *}$ \\
Both College Graduates & {$[0.0123]$} \\
& $0.0922^{* * *}$ \\
Constant & {$[0.0104]$} \\
& $0.785^{* * * *}$ \\
& {$[0.0313]$} \\
Observations & \\
R-squared & 6358 \\
Standard errors in brackets & 0.889 \\
$* * *$ & $0<0.01, * * 0<0.05, * 0<0.1$
\end{tabular}

Own estimates from the PSID 1980-1997. Sample includes married households whose head is white, male and ages 25 to 55. The coefficients reported are the estimates of equation (9) in the text.

Table 6: Regional Job offers

\begin{tabular}{lcc}
\hline \hline & $\begin{array}{c}\text { Probability of a Job Offer } \\
\text { From Each Region }\left(\phi_{R}\right)\end{array}$ & $\begin{array}{c}\text { Actual Moves } \\
\text { to Each Region (PSID) }\end{array}$ \\
\hline New England & 0.034 & 0.05 \\
Middle Atlantic & 0.09 & 0.06 \\
East North Central & 0.05 & 0.08 \\
West North Central & 0.12 & 0.04 \\
South Atlantic & 0.1 & 0.25 \\
East South Central & 0.12 & 0.11 \\
West South Central & 0.12 & 0.13 \\
Mountain & 0.2 & 0.11 \\
Pacific & 0.166 & 0.13 \\
\hline
\end{tabular}

The first column shows the calibrated values of parameters $\phi_{R}$ (See equation (6) in the text). The second column displays the actual share of movers going to each region in the PSID 1984-1997. 
Table 7: Moments Used in the Estimation of the Structural Parameters

\begin{tabular}{c}
\hline \hline Mobility Rates: 16 Moments \\
\hline Mobility by age groups $([<=29],[30,35],[36,44],[>=45])$ \\
Mobility by number of children \\
Mobility by home tenure status \\
Average number of moves by education \\
Average number of moves by whether head was living in his region of birth in 1984 \\
\hline \hline Housing: 8 Moments \\
\hline Share of homeowners who sell their houses by year \\
Number of times that individuals buy a house \\
Average rooms per capita \\
Average rooms per capita growth \\
Homeownership rates by education \\
\hline \hline Total Labor Income: 30 Moments \\
\hline Average total labor income by education of the couple \\
A36,37],[38,39],[40,42],[ $>=43])$ \\
Average total labor income by region \\
Standard deviation of total labor income by region \\
Autocorrelation of total labor income
\end{tabular}


Table 8: Parameter Estimates: Preferences

\begin{tabular}{|c|c|}
\hline Risk Aversion Parameter $(\sigma)$ & $\begin{array}{c}2.79 \\
(6.1 \mathrm{E}-05)\end{array}$ \\
\hline Housing Budget Share Parameter $(1-a)$ & $\begin{array}{l}\text { 7.37E-05 } \\
(6.9 \mathrm{E}-12)\end{array}$ \\
\hline Intra-temporal Elasticity of Substitution $(\eta)$ & $\begin{array}{c}0.539 \\
(6.9 \mathrm{E}-07)\end{array}$ \\
\hline Preference for Homeownership $(\kappa)$ & $\begin{array}{c}2.73 \\
(0.01)\end{array}$ \\
\hline Preference for Home Location $\left(b_{h}\right)$ & $\begin{array}{l}5.03 E-09 \\
(1.3 E-19)\end{array}$ \\
\hline Proportion of Households with $b_{h}>0\left(\pi_{b}\right)$ & $\begin{array}{c}0.94 \\
(1.2 \mathrm{E}-04)\end{array}$ \\
\hline Bequest Parameter $(\gamma)$ & $\begin{array}{c}74.71 \\
(23.46)\end{array}$ \\
\hline
\end{tabular}

Cells report the estimated coefficients of equation (3) in text. Standard errors in parentheses. 
Table 9: Parameter Estimates: Moving Costs, Transaction Costs and Job Offers Equation

\begin{tabular}{|c|c|c|c|c|c|}
\hline \multicolumn{2}{|c|}{ Moving Costs } & \multicolumn{2}{|c|}{ Transaction Costs } & \multicolumn{2}{|c|}{ Job Offers Equation } \\
\hline$m_{0}$ & $\begin{array}{c}2,613.32 \\
(441.0)\end{array}$ & $q_{b}$ & $\begin{array}{c}0.17 \\
(0.00043)\end{array}$ & $\alpha_{0}$ & $\begin{array}{c}-0.28 \\
(0.00087)\end{array}$ \\
\hline \multirow[t]{4}{*}{$m_{1}$} & $\begin{array}{c}2582.87 \\
(514.3)\end{array}$ & $q_{s}$ & $\begin{array}{c}0.10 \\
(0.000085)\end{array}$ & $\alpha_{1}$ & $\begin{array}{c}0.02 \\
(0.12)\end{array}$ \\
\hline & & & & $\alpha_{2}$ & $\begin{array}{c}0.34 \\
(0.02)\end{array}$ \\
\hline & & & & $\alpha_{3}$ & $\begin{array}{c}0.47 \\
(0.01)\end{array}$ \\
\hline & & & & $\alpha_{4}$ & $\begin{array}{c}-0.03 \\
(4.7 \mathrm{E}-07)\end{array}$ \\
\hline
\end{tabular}

$m_{0}$ and $m_{1}$ are the fixed moving cost and the moving cost per children. $q_{b}$ and $q_{s}$ are the transaction costs of buying and selling a house (fraction of the home value). Reported coefficients of the job offer equation correspond to equation (5) in text. Standard errors in parentheses. 
Table 10: Parameter Estimates: Labor Income Equation

\begin{tabular}{lc}
\hline \hline Head HS Graduate and Spouse College Graduate & 0.05 \\
Head College graduate and Spouse HS Graduate & $(0.01759)$ \\
& 0.26 \\
Both Head and Spouse College Graduates & $0.00039)$ \\
& 0.49 \\
Age & $(0.00044)$ \\
Age-squared & 0.08 \\
& $(0.00125)$ \\
Middle Atlantic & -0.0007 \\
& $(2.6 \mathrm{E}-08)$ \\
East North Central & -0.06 \\
& $(0.00202)$ \\
West North Central & 0.03 \\
& $(0.00202)$ \\
South Atlantic & -0.16 \\
& $(0.00043)$ \\
East South Central & 0.04 \\
& $(0.00007)$ \\
West South Central & -0.09 \\
& $(0.00024)$ \\
Mountain & -0.19 \\
Pacific & $(0.00027)$ \\
Constant & -0.06 \\
& $(0.00088)$ \\
& -0.02 \\
& $(0.00043)$ \\
& 8.40 \\
& $(0.00005)$ \\
\hline
\end{tabular}

Cells report coefficients of equation (4) in text. Standard errors in parentheses. 
Table 11: Parameter Estimates: Labor Income Shocks

\begin{tabular}{lc}
\hline \hline \multicolumn{2}{c}{ Shocks } \\
Standard Deviation of Shocks by Region \\
\hline New England & 0.10 \\
& $(0.00001)$ \\
Middle Atlantic & 0.08 \\
& $(0.00028)$ \\
East North Central & 0.10 \\
& $(0.00021)$ \\
West North Central & 0.09 \\
& $(0.00002)$ \\
South Atlantic & 0.08 \\
& $(0.00031)$ \\
East South Central & 0.11 \\
& $(0.00024)$ \\
West South Central & 0.11 \\
& $(0.00020)$ \\
Mountain & 0.05 \\
& $(0.00061)$ \\
Pacific & 0.06 \\
& $(0.00008)$ \\
\multicolumn{1}{c}{ Persistence of Shocks } \\
\end{tabular}

Standard errors in parentheses. 
Table 12: Model Fit: Mobility Rates

\begin{tabular}{ccccc}
\hline \hline \multirow{3}{*}{ By Number of Children } & & Data & Model \\
\cline { 3 - 4 } & 0 & & \\
1 & 0.0256 & 0.0241 \\
2 & 0.0246 & 0.0177 \\
$>=3$ & 0.0156 & 0.0160 \\
& & 0.0175 & 0.0177
\end{tabular}

By Head's Age

$\begin{array}{lll}{[<=29]} & 0.0295 & 0.0329 \\ {[30,35]} & 0.0243 & 0.0200 \\ {[36,44]} & 0.0164 & 0.0150 \\ {[>=45]} & 0.0074 & 0.0102\end{array}$

By Home Tenure Status

$\begin{array}{ccc}\text { Renters } & 0.0439 & 0.0314 \\ \text { Homeowners } & 0.0144 & 0.0148\end{array}$

No of Moves by Education

$\begin{array}{ccc}\text { Both HS Graduates } & 0.1648 & 0.1558 \\ \text { Head HS Graduate and Spouse College Graduate } & 0.1951 & 0.1425 \\ \text { Spouse HS Graduate and Head College graduate } & 0.3425 & 0.2516 \\ \text { Both College Graduates } & 0.2952 & 0.3092\end{array}$

No of Moves by Wheter head lives in region of birth in 1984

$\begin{array}{ccc}\text { Not in his region of birth } & 0.5703 & 0.4483 \\ \text { Lives in his region of birth } & 0.1106 & 0.1222\end{array}$


Table 13: Model Fit: Housing Moments

\begin{tabular}{lrr}
\hline \hline & Data & Model \\
\cline { 2 - 3 } & & \\
Share of Homeowners who sell their homes & 0.055 & 0.069 \\
Number of Times that individuals buy a house & 0.720 & 0.817 \\
& & \\
Average rooms per capita & 1.870 & 1.865 \\
& & \\
Average rooms per capita growth & 1.023 & 1.005 \\
& & \\
Homeownership by Education & & \\
Both HS Graduates & 0.839 & 0.836 \\
Head HS Graduate and Spouse College Graduate & 0.869 & 0.910 \\
$\begin{array}{l}\text { Spouse HS Graduate and Head College graduate } \\
\text { Both College Graduates }\end{array}$ & 0.864 & 0.866 \\
& 0.866 & 0.864 \\
\hline
\end{tabular}

Table 14: Robustness Check: Labor Income, Labor Income Growth and Number of Children by Home Tenure Status

\begin{tabular}{|c|c|c|c|c|c|c|}
\hline & \multicolumn{2}{|c|}{ Average Log Labor income } & \multicolumn{2}{|c|}{ Average Log Labor Income Growth } & \multicolumn{2}{|c|}{ Average Number of Children } \\
\hline & Model & Data & Model & Data & Model & Data \\
\hline Renters & $\begin{array}{r}10.20 \\
(0.57)\end{array}$ & $\begin{array}{r}10.20 \\
(0.55)\end{array}$ & $\begin{array}{r}0.093 \\
(0.33)\end{array}$ & $\begin{array}{r}0.050 \\
(0.46)\end{array}$ & $\begin{array}{c}1.74 \\
(1.03)\end{array}$ & $\begin{array}{c}1.63 \\
(1.03)\end{array}$ \\
\hline Homeowners & $\begin{array}{c}10.56 \\
(0.48)\end{array}$ & $\begin{array}{l}10.56 \\
(0.52)\end{array}$ & $\begin{array}{l}0.027 \\
(0.31)\end{array}$ & $\begin{array}{c}0.032 \\
(0.31)\end{array}$ & $\begin{array}{c}1.76 \\
(0.95)\end{array}$ & $\begin{array}{c}1.78 \\
(0.94)\end{array}$ \\
\hline
\end{tabular}

Standard Deviation in parentheses 
Table 15: Robustness Check: Regional Migration Patterns

\begin{tabular}{|c|c|c|c|c|}
\hline & \multicolumn{2}{|c|}{ Share moving to each region } & \multicolumn{2}{|c|}{ Share moving from each region } \\
\hline & Model & Data & Model & Data \\
\hline New England & 3.2 & 5.6 & 6.3 & 5.7 \\
\hline Middle Atlantic & 8.0 & 6.3 & 12.0 & 13.1 \\
\hline East North Central & 10.0 & 8.4 & 6.7 & 11.5 \\
\hline West North Central & 5.8 & 4.2 & 17.0 & 8.2 \\
\hline South Atlantic & 19.1 & 25.9 & 7.2 & 14.8 \\
\hline East South Central & 12.8 & 11.9 & 6.9 & 8.2 \\
\hline West South Central & 12.1 & 13.3 & 14.9 & 14.8 \\
\hline Mountain & 16.5 & 11.9 & 11.4 & 13.9 \\
\hline Pacific & 12.5 & 12.6 & 17.7 & 9.8 \\
\hline Total & 100 & 100 & 100 & 100 \\
\hline
\end{tabular}

Table 16: Robustness Check: Data vs. Simulated Diffs-in-Diffs

\begin{tabular}{|c|c|c|c|c|c|c|}
\hline & \multicolumn{3}{|c|}{ Dependent Variable: Moved } & \multicolumn{3}{|c|}{ Dependent Variable: Household Labor Income } \\
\hline & Control & Data & \begin{tabular}{c}
\multicolumn{1}{c}{ Simulations } \\
Control Group: Renters
\end{tabular} & Control & tap: Renters & $\begin{array}{c}\text { Simulations } \\
\text { Control Group: Renters }\end{array}$ \\
\hline & $\begin{array}{l}\text { All } \\
(1)\end{array}$ & $\begin{array}{c}\text { Model's Sample } \\
\text { (2) }\end{array}$ & 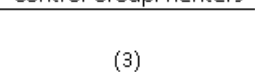 & $\begin{array}{l}\text { All } \\
\text { (4) }\end{array}$ & $\begin{array}{c}\text { Model's Sample } \\
\text { (5) }\end{array}$ & 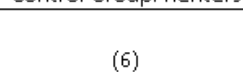 \\
\hline Homeowner & $\begin{array}{c}-0.0174^{* * * *} \\
{[0.00386]}\end{array}$ & $\begin{array}{c}-0.00634 \\
{[0.00709]}\end{array}$ & $\begin{array}{c}-0.00920^{* * *} \\
{[0.000736]}\end{array}$ & $\begin{array}{l}0.0976^{* * *} \\
{[0.00972]}\end{array}$ & $\begin{array}{c}0.0850^{* * *} \\
{[0.0153]}\end{array}$ & $\begin{array}{l}0.158^{* * *} \\
{[0.00927]}\end{array}$ \\
\hline $\operatorname{shock}(\mathrm{t}=\mathrm{t} 0)$ & $\begin{array}{c}0.0416^{* * *} \\
{[0.0114]}\end{array}$ & $\begin{array}{c}0.0380 \\
{[0.0285]}\end{array}$ & $\begin{array}{l}0.0504^{* * *} \\
{[0.00380]}\end{array}$ & $\begin{array}{c}-0.157^{* * * *} \\
{[0.0338]}\end{array}$ & $\begin{array}{c}-0.376^{* * *} \\
{[0.0694]}\end{array}$ & $\begin{array}{l}-0.440^{* * * *} \\
{[0.00871]}\end{array}$ \\
\hline $\operatorname{shock}(t>=t 0+1)$ & & & & $\begin{array}{c}-0.107^{* * * *} \\
{[0.0263]}\end{array}$ & $\begin{array}{c}-0.131^{* * *} \\
{[0.0471]}\end{array}$ & $\begin{array}{l}-0.351^{* * *} \\
{[0.00818]}\end{array}$ \\
\hline Homeowner $x$ shock $(t=t 0)$ & $\begin{array}{c}-0.0383^{* * *} \\
{[0.0139]}\end{array}$ & $\begin{array}{c}-0.0345 \\
{[0.0320]}\end{array}$ & $\begin{array}{c}-0.0258^{* * *} \\
{[0.00397]}\end{array}$ & $\begin{array}{c}-0.0433 \\
{[0.0404]}\end{array}$ & $\begin{array}{l}0.172^{* *} \\
{[0.0774]}\end{array}$ & $\begin{array}{c}-0.0341 * * * \\
{[0.0104]}\end{array}$ \\
\hline Homeowner $x \operatorname{shock}(t=t 0+1)$ & & & & $\begin{array}{c}-0.0668 * * \\
{[0.0301]}\end{array}$ & $\begin{array}{l}-0.0952^{*} \\
{[0.0517]}\end{array}$ & $\begin{array}{c}-0.0664^{* * * *} \\
{[0.00797]}\end{array}$ \\
\hline Constant & $\begin{array}{l}0.0317^{* * *} \\
{[0.00797]}\end{array}$ & $\begin{array}{l}0.00399 \\
{[0.0265]}\end{array}$ & $\begin{array}{l}0.0323^{* * *} \\
{[0.00402]}\end{array}$ & $\begin{array}{l}10.57^{* * *} \\
{[0.0212]}\end{array}$ & $\begin{array}{l}10.09 * * * \\
{[0.0578]}\end{array}$ & $\begin{array}{l}9.924^{* * * *} \\
{[0.0615]}\end{array}$ \\
\hline No of Households & 2477 & 571 & 571 & 2477 & 571 & 571 \\
\hline Households $\times$ Years & 23383 & 6935 & 6935 & 23383 & 6935 & 6935 \\
\hline
\end{tabular}

Columns (1) and (4) reproduce the results of Table 2. Columns (2) and (5) show results restricting the sample to households included in the model's sample. Columns (3) and (6) show the estimates of the same equation using simulated data and defining a negative shock as a $20 \%$ income drop. 
Table 17: The Effect of Negative Labor Market Shocks

\begin{tabular}{|c|c|c|c|c|}
\hline & \multicolumn{2}{|c|}{ Dependent Variable: Moved } & \multirow{2}{*}{\multicolumn{2}{|c|}{$\begin{array}{c}\text { Dependent Variable: Household Labor Income } \\
\text { Control Group: }\end{array}$}} \\
\hline & Cont & Group: & & \\
\hline & $\begin{array}{c}\text { Renters } \\
\text { (1) }\end{array}$ & $\begin{array}{c}\text { Counterfactual } \\
\text { (2) }\end{array}$ & $\begin{array}{c}\text { Renters } \\
\text { (3) }\end{array}$ & $\begin{array}{c}\text { Counterfactual } \\
\text { (4) }\end{array}$ \\
\hline Homeowners & $\begin{array}{c}-0.00920^{* * *} \\
{[0.000736]}\end{array}$ & $\begin{array}{c}-0.00525^{* * *} \\
{[0.000254]}\end{array}$ & $\begin{array}{l}0.158^{* * *} \\
{[0.00927]}\end{array}$ & $\begin{array}{c}-0.000950^{* * *} \\
{[0.000150]}\end{array}$ \\
\hline $\operatorname{shock}(\mathrm{t}=\mathrm{t} 0)$ & $\begin{array}{l}0.0504^{* * *} \\
{[0.00380]}\end{array}$ & $\begin{array}{l}0.0280^{* * *} \\
{[0.00135]}\end{array}$ & $\begin{array}{l}-0.440 * * * \\
{[0.00871]}\end{array}$ & $\begin{array}{l}-0.417^{* * *} \\
{[0.00415]}\end{array}$ \\
\hline $\operatorname{shock}(t »=t 0+1)$ & & & $\begin{array}{l}-0.351 * * * \\
{[0.00818]}\end{array}$ & $\begin{array}{l}-0.382^{* * *} \\
{[0.00563]}\end{array}$ \\
\hline Homeowner $x \operatorname{shock}(t=t 0)$ & $\begin{array}{c}-0.0258^{* * * *} \\
{[0.00397]}\end{array}$ & $\begin{array}{c}-0.00439^{* * *} \\
{[0.000586]}\end{array}$ & $\begin{array}{c}-0.0341^{* * *} \\
{[0.0104]}\end{array}$ & $\begin{array}{c}-0.00414^{* * * *} \\
{[0.000447]}\end{array}$ \\
\hline Homeowner $x$ shock $(t>=t 0+1)$ & & & $\begin{array}{c}-0.0664^{* * *} \\
{[0.00797]}\end{array}$ & $\begin{array}{c}-0.00552^{* * * *} \\
{[0.000525]}\end{array}$ \\
\hline Constant & $\begin{array}{l}0.0323^{* * *} \\
{[0.00402]}\end{array}$ & $\begin{array}{l}0.0120^{* * *} \\
{[0.00285]}\end{array}$ & $\begin{array}{l}9.924^{* * *} \\
{[0.0615]}\end{array}$ & $\begin{array}{l}9.867^{* * *} \\
{[0.0592]}\end{array}$ \\
\hline
\end{tabular}

Each column shows estimates of equation (10) in the text. Columns (1) and (3) use renters as the control group. Columns (2) and (4) restrict the sample to homeowners and use the model's counterfactual as the control group. I define a negative shock as an income drop of at least $20 \%$ in the current location. 
Table 18: The Effect of Job Offers

\begin{tabular}{|c|c|c|c|c|}
\hline & \multirow{2}{*}{\multicolumn{2}{|c|}{$\begin{array}{c}\text { Dependent Variable: Moved } \\
\text { Control Group: }\end{array}$}} & \multirow{2}{*}{\multicolumn{2}{|c|}{$\begin{array}{c}\text { Dependent Variable: Household Labor Income } \\
\text { Control Group: }\end{array}$}} \\
\hline & & & & \\
\hline & $\begin{array}{c}\text { Renters } \\
\text { (1) }\end{array}$ & $\begin{array}{c}\text { Counterfactual } \\
\text { (2) } \\
\end{array}$ & $\begin{array}{c}\text { Renters } \\
\text { (3) }\end{array}$ & $\begin{array}{l}\text { Counterfactual } \\
\text { (4) }\end{array}$ \\
\hline Homeowners & $\begin{array}{c}-0.00542^{* * *} \\
{[0.000618]}\end{array}$ & $\begin{array}{c}-0.00620^{* * * *} \\
{[0.000351]}\end{array}$ & $\begin{array}{l}0.183^{* * *} \\
{[0.00975]}\end{array}$ & $\begin{array}{c}-0.00221^{* * *} \\
{[0.000472]}\end{array}$ \\
\hline shock $(\mathrm{t}=\mathrm{t} 0)$ & $\begin{array}{l}0.470^{* * *} \\
{[0.0188]}\end{array}$ & $\begin{array}{l}0.301^{* * *} \\
{[0.0117]}\end{array}$ & $\begin{array}{l}0.231 * * * \\
{[0.0112]}\end{array}$ & $\begin{array}{l}0.196^{* * *} \\
{[0.00785]}\end{array}$ \\
\hline $\operatorname{shock}(t>=t 0+1)$ & & & $\begin{array}{l}0.129 * * * \\
{[0.00817]}\end{array}$ & $\begin{array}{c}0.0867^{* * *} \\
{[0.00705]}\end{array}$ \\
\hline Homeowner $x$ shock $(\mathrm{t}=\mathrm{t} 0)$ & $\begin{array}{c}-0.216^{* * *} \\
{[0.0181]}\end{array}$ & $\begin{array}{c}-0.0509 * * * \\
{[0.00292]}\end{array}$ & $\begin{array}{c}-0.0659^{* * *} \\
{[0.0121]}\end{array}$ & $\begin{array}{c}-0.0219 * * * \\
{[0.00149]}\end{array}$ \\
\hline Homeowner $x$ shock $(t>=t 0+1)$ & & & $\begin{array}{c}-0.0505^{* * * *} \\
{[0.00890]}\end{array}$ & $\begin{array}{c}-0.0100^{* * *} \\
{[0.00132]}\end{array}$ \\
\hline Constant & $\begin{array}{l}0.0215^{* * *} \\
{[0.00359]}\end{array}$ & $\begin{array}{c}0.00806 \\
{[0.00737]}\end{array}$ & $\begin{array}{l}9.941^{* * *} \\
{[0.0631]}\end{array}$ & $\begin{array}{l}10.06^{* * *} \\
{[0.0852]}\end{array}$ \\
\hline
\end{tabular}

Each column shows estimates of equation (10) in the text. Columns (1) and (3) use renters as the control group. Columns (2) and (4) restrict the sample to homeowners and use the model's counterfactual as the control group. I define a positive shock as a job offer in another location that implies an income increase of at least $20 \%$.

Table 19: Characteristics of Owners and Renters

$\%$ Receiving Job Offers No. of Children $\%$ Home-Type $\%$ Living at Home Location

$\begin{array}{lllll}\text { Renters } & 16.4 \% & 1.7 & 92.8 \% & 63.5 \% \\ \text { Owners } & 13.0 \% & 1.8 & 93.8 \% & 75.5 \%\end{array}$


Table 20: The Effect of Income and Housing Shocks

\begin{tabular}{|c|c|c|}
\hline & Moved & $\log ($ Labor Income $)$ \\
\hline income shock $(\mathrm{t}=\mathrm{t} 0)$ & $\begin{array}{l}0.0260^{* 4+4 * *} \\
{[0.00175]}\end{array}$ & $\begin{array}{c}-0.433^{*+* * *} \\
{[0.0186]}\end{array}$ \\
\hline income $\operatorname{shock}(t>=t 0+1)$ & & $\begin{array}{c}-0.0846^{*+\% *} \\
{[0.0162]}\end{array}$ \\
\hline housing shock $(\mathrm{t}=\mathrm{t} 0)$ & $\begin{array}{c}-0.00561^{\text {*4+\%* }} \\
{[0.000759]}\end{array}$ & $\begin{array}{c}0.0191 \\
{[0.0178]}\end{array}$ \\
\hline housing shock $(\mathrm{t}>=\mathrm{t} 0+1)$ & & $\begin{array}{c}0.0246 \\
{[0.0161]}\end{array}$ \\
\hline both $\operatorname{shocks}(t=t 0)$ & $\begin{array}{l}0.000485 \\
{[0.00255]}\end{array}$ & $\begin{array}{l}-0.0294 \\
{[0.0184]}\end{array}$ \\
\hline both shocks $(\mathrm{t}>=\mathrm{t} 0+1)$ & & $\begin{array}{c}-0.0305^{*} \\
{[0.0168]}\end{array}$ \\
\hline Home Owner & $\begin{array}{c}-0.00808^{\text {*t+2** }} \\
{[0.000977]}\end{array}$ & $\begin{array}{l}0.158^{\text {*t+4*- }} \\
{[0.0141]}\end{array}$ \\
\hline Constant & $\begin{array}{l}0.0217^{*+\div+* *} \\
{[0.00113]}\end{array}$ & $\begin{array}{l}10.47^{\text {*+*=* }} \\
{[0.0202]}\end{array}$ \\
\hline
\end{tabular}

Robust standard errors in brackets

$* * * * 0<0.01, * * \mathrm{p}<0.05, * \mathrm{p}<0.1$

Each column reports estimates of equation (11) in the text. I define a negative income shock as a income drop of at least $10 \%$ in the current location. A housing shock is a decrease of at least $10 \%$ in the value of the current residence. 
Table 21: Eliminating the Home Mortgage Deduction: Changes in Homeownership Rates, House Size, Mobility and Labor Income. By Income Quintiles

\begin{tabular}{|c|c|c|c|c|c|c|}
\hline \multirow{2}{*}{$\begin{array}{l}\text { Income } \\
\text { Quintiles } \\
\text { (1) }\end{array}$} & \multirow{2}{*}{$\begin{array}{l}\text { Mean Tax Incentive } \\
\text { (\% of net income) } \\
\text { (2) }\end{array}$} & \multicolumn{2}{|c|}{ Effect of the Policy Change } & \multirow{2}{*}{$\begin{array}{c}\text { Homeownership } \\
\text { after Moving (baseline) } \\
\text { (5) }\end{array}$} & \multicolumn{2}{|c|}{ Effect of the Policy Change } \\
\hline & & $\begin{array}{l}\text { Homeownership } \\
\text { (3) }\end{array}$ & $\begin{array}{c}\text { Rooms } \\
\text { (4) }\end{array}$ & & $\begin{array}{c}\text { Moved } \\
(6) \\
\end{array}$ & $\begin{array}{c}\text { Log(Labor Income) } \\
(7) \\
\end{array}$ \\
\hline 1 & $1.5 \%$ & $\begin{array}{l}-0.0531^{* \alpha *} \\
{[0.00593]}\end{array}$ & $\begin{array}{l}-0.0134 \\
{[0.0223]}\end{array}$ & 0.17 & $\begin{array}{l}0.00197^{* \ldots \times} \\
{[0.000223]}\end{array}$ & $\begin{array}{l}0.00710^{* \alpha * \alpha} \\
{[0.000479]}\end{array}$ \\
\hline 2 & $2.3 \%$ & $\begin{array}{l}-0.0629^{\text {xax }} \\
{[0.00481]}\end{array}$ & $\begin{array}{l}-0.0419^{*} \\
{[0.0240]}\end{array}$ & 0.24 & $\begin{array}{l}0.00181^{\text {*a* }} \\
{[0.000252]}\end{array}$ & $\begin{array}{l}0.00412^{\text {*a**; }} \\
{[0.000370]}\end{array}$ \\
\hline 3 & $2.9 \%$ & $\begin{array}{l}-0.0519^{* x+x} \\
{[0.00448]}\end{array}$ & $\begin{array}{l}-0.120^{* * x} \\
{[0.0250]}\end{array}$ & 0.36 & $\begin{array}{l}0.000876^{* * *} \\
{[0.000244]}\end{array}$ & $\begin{array}{l}0.00103^{\text {**ax }} \\
{[0.000387]}\end{array}$ \\
\hline 4 & $3.3 \%$ & $\begin{array}{l}-0.0267^{x+\alpha x} \\
{[0.00387]}\end{array}$ & $\begin{array}{l}-0.263^{x+\alpha x} \\
{[0.0242]}\end{array}$ & 0.54 & $\begin{array}{c}0.000123 \\
{[0.000272]}\end{array}$ & $\begin{array}{l}-0.00220^{* x+\infty} \\
{[0.000430]}\end{array}$ \\
\hline 5 & $3.4 \%$ & $\begin{array}{l}-0.00430 \\
{[0.00431]}\end{array}$ & $\begin{array}{l}-0.446^{x+x} \\
{[0.0357]}\end{array}$ & 0.69 & $\begin{array}{l}-0.00197^{* \alpha * x} \\
{[0.000366]}\end{array}$ & $\begin{array}{l}-0.0126^{x+x} \\
{[0.00101]}\end{array}$ \\
\hline
\end{tabular}

Column (2) shows the average ratio between the tax incentive and after tax labor income. Columns (3) and (4) report the effect of the policy on homeownership rates and average number of rooms. Column (5) shows the fraction of movers who buy a house in the year they move, in the baseline. Columns (6) and (7) report the effect of the policy change on mobility rates and labor income. 
Table 22: Eliminating the Downpayment Requirement to Buy a House: Effect on Homeownership Rates, House Size, Mobility and Labor Income

\begin{tabular}{|c|c|c|c|c|c|c|}
\hline \multirow{2}{*}{$\begin{array}{l}\text { Income } \\
\text { Quintiles } \\
\text { (1) }\end{array}$} & \multicolumn{4}{|c|}{ All Households } & \multicolumn{2}{|c|}{$\begin{array}{l}\text { New Owners who experience } \\
\text { Negative Income shocks }\end{array}$} \\
\hline & $\begin{array}{l}\text { Homeownership } \\
\text { (2) }\end{array}$ & $\begin{array}{c}\text { Rooms } \\
\text { (3) }\end{array}$ & $\begin{array}{c}\text { Moved } \\
\text { (4) }\end{array}$ & $\begin{array}{c}\text { Log(Labor Income) } \\
(5)\end{array}$ & $\begin{array}{c}\text { Moved } \\
(6)\end{array}$ & $\begin{array}{c}\text { Log(Labor Income) } \\
(7) \\
\end{array}$ \\
\hline 1 & $\begin{array}{l}0.180^{* \infty \alpha} \\
{[0.0132]}\end{array}$ & $\begin{array}{l}-0.0563 \\
{[0.0431]}\end{array}$ & $\begin{array}{l}0.00242^{2 * 3} \\
{[0.000466]}\end{array}$ & $\begin{array}{l}0.0257^{* * *} \\
{[0.00153]}\end{array}$ & $\begin{array}{l}-0.00479^{*+\infty *} \\
{[0.00110]}\end{array}$ & $\begin{array}{c}0.00155 \\
{[0.00202]}\end{array}$ \\
\hline 2 & $\begin{array}{c}0.133^{* \times *} \\
{[0.00909]}\end{array}$ & $\begin{array}{l}-0.0420 \\
{[0.0408]}\end{array}$ & $\begin{array}{c}0.00105^{*} \\
{[0.000625]}\end{array}$ & $\begin{array}{l}0.0149 * * * * \\
{[0.00117]}\end{array}$ & $\begin{array}{l}-0.0356^{* x *} \\
{[0.00409]}\end{array}$ & $\begin{array}{l}-0.0498^{* * *} \\
{[0.00510]}\end{array}$ \\
\hline 3 & $\begin{array}{l}0.0908^{* 3 \times 3} \\
{[0.00636]}\end{array}$ & $\begin{array}{l}0.117^{* * \alpha *} \\
{[0.0319]}\end{array}$ & $\begin{array}{l}-0.000737 \\
{[0.000646]}\end{array}$ & $\begin{array}{l}0.00368^{* * \alpha} \\
{[0.00111]}\end{array}$ & $\begin{array}{l}-0.0956^{* \times *} \\
{[0.0108]}\end{array}$ & $\begin{array}{l}-0.138^{* * * *} \\
{[0.0116]}\end{array}$ \\
\hline 4 & $\begin{array}{l}0.0621^{1 * \alpha *} \\
{[0.00492]}\end{array}$ & $\begin{array}{l}0.220^{* * \alpha *} \\
{[0.0310]}\end{array}$ & $\begin{array}{l}-0.00163^{\text {** }} \\
{[0.000683]}\end{array}$ & $\begin{array}{l}-0.0106^{* \times * *} \\
{[0.00116]}\end{array}$ & $\begin{array}{l}-0.117^{* \times *} \\
{[0.0208]}\end{array}$ & $\begin{array}{l}-0.232^{2 * \alpha *} \\
{[0.0252]}\end{array}$ \\
\hline 5 & $\begin{array}{l}0.0643^{* * *} \\
{[0.00642]}\end{array}$ & $\begin{array}{l}0.189^{* * * *} \\
{[0.0390]}\end{array}$ & $\begin{array}{l}-0.00755^{* * * *} \\
{[0.00121]}\end{array}$ & $\begin{array}{l}-0.0433^{*+3 *} \\
{[0.00289]}\end{array}$ & $\begin{array}{l}-0.173^{* * *} \\
{[0.0251]}\end{array}$ & $\begin{array}{l}-0.367^{* * *} \\
{[0.0359]}\end{array}$ \\
\hline
\end{tabular}


Figure 1: Mobility, Labor Income and Fertility. Before and After Buying a House

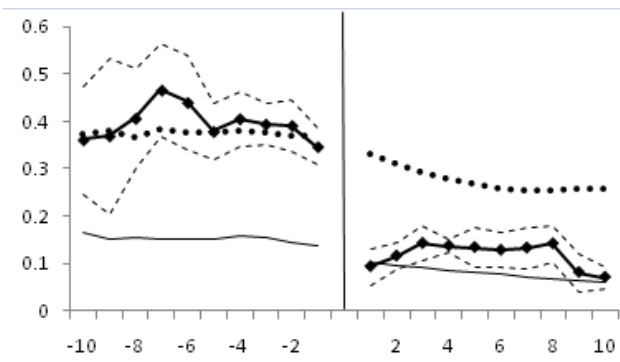

(a) Total Mobility

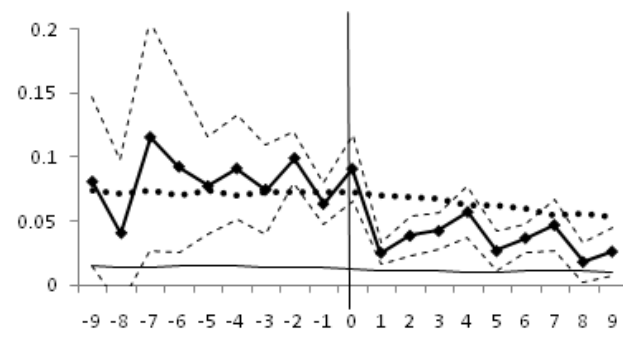

(b) Inter-State Mobility

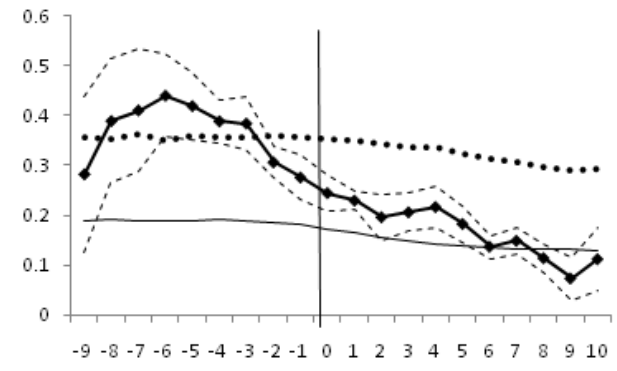

(c) Job Mobility

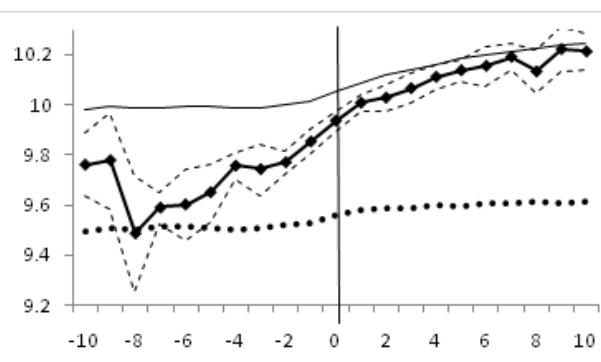

(d) HH Head's Labor Incom

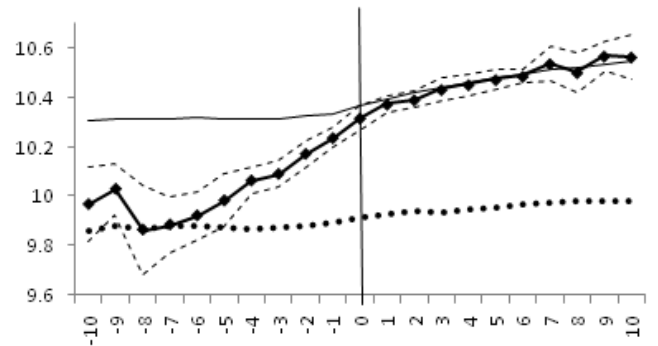

(e) Total Labor Income
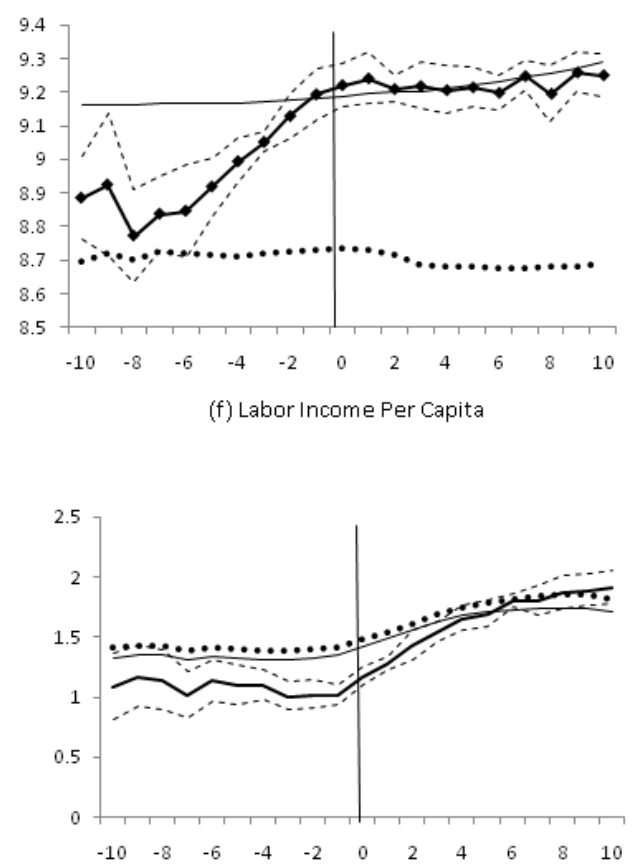

(g) Number of Children

Own estimates from the PSID 1980-1997. Sample includes married households whose head is white, male and ages 25 to $55(\mathrm{~N}=22,745)$. See Section 3.1 for details. 
Figure 2: Mortgage Interest Rate by Year

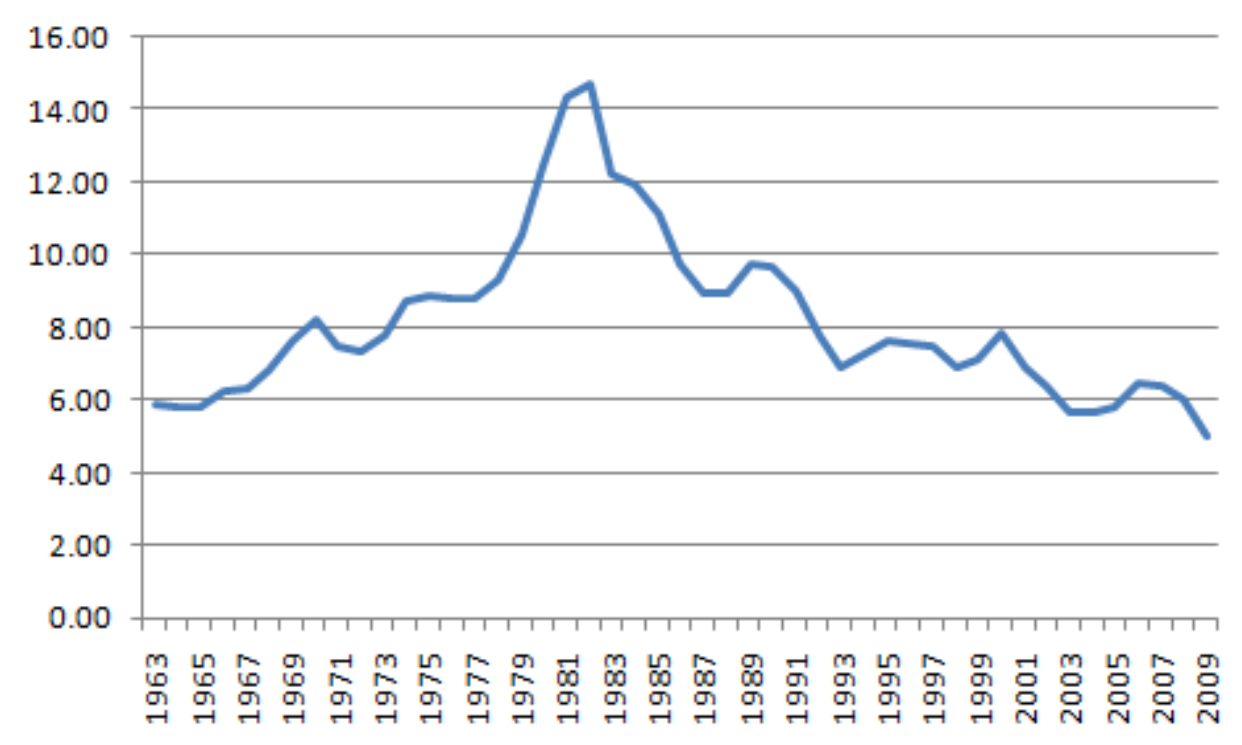

Contract Interest Rate on single-family mortgages, annual national averages, all homes. Source: Monthly Interest Rate Survey, Federal Housing Finance Agency (FHFA). 
Figure 3: Identification of Structural Parameters: Relationship between selected moments and parameters, at parameter estimates

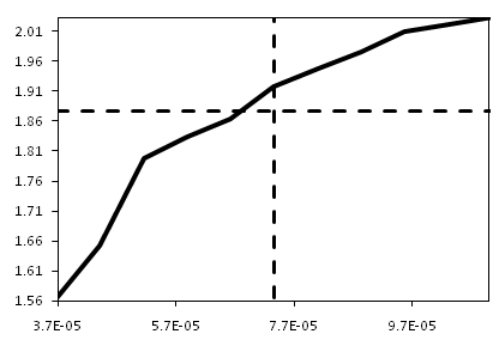

(a) Rooms per cap vs Housing Budget Share $(a)$

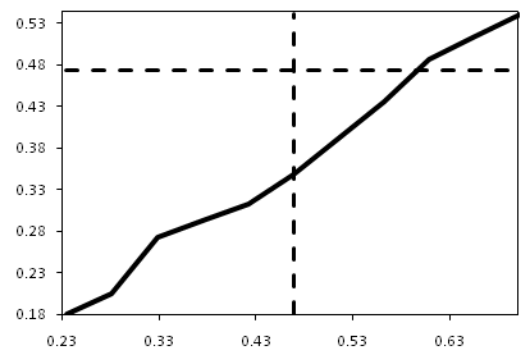

(d) College Grad' Mobility vs Coll. Premium $\left(\alpha_{3}\right)$

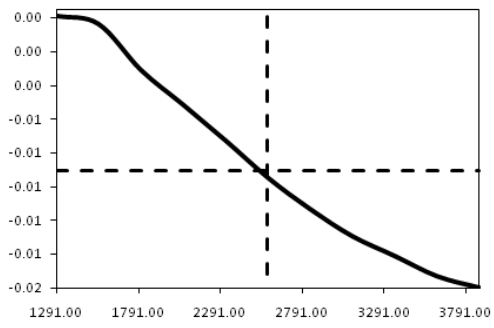

(g) Diff. mobility by no. of children vs moving cost of children $\left(m_{1}\right)$

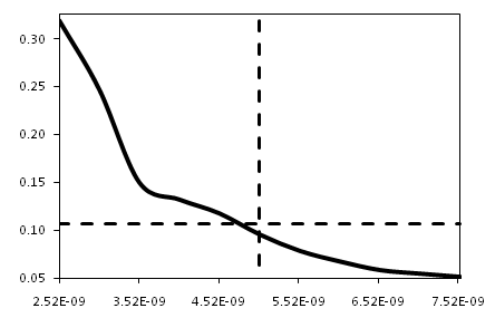

(j) Mobility from Home Location vs Taste for home $\left(b_{h}\right)$

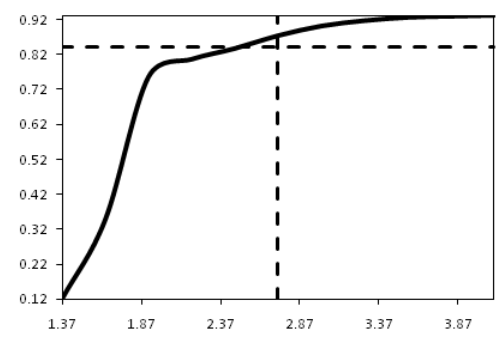

(b) Homeownership vs Taste for Homeownership $(\kappa)$

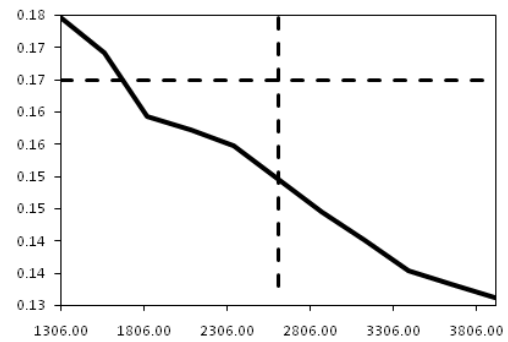

(e) HS Graduates' Mobility vs Fixed Moving Cost $\left(m_{0}\right)$

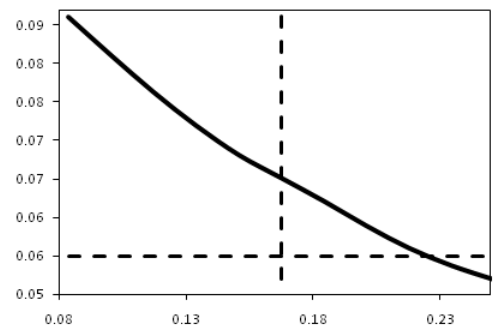

(h) Share selling house vs cost of selling $\left(q_{s}\right)$

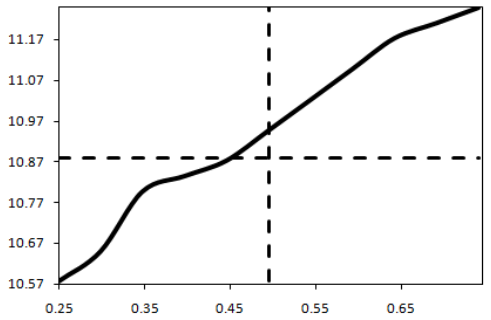

(k) College Grad's Income vs College Premium $\left(\beta_{e d u, 3}\right)$

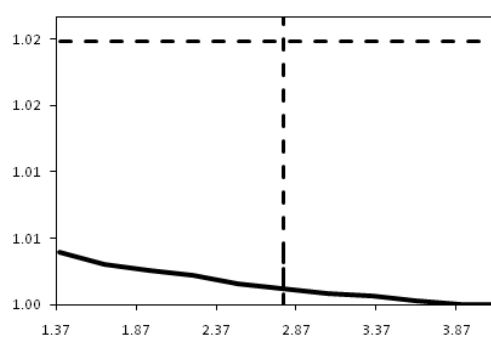

(c) Rooms per cap growth vs risk aversion $(\sigma)$

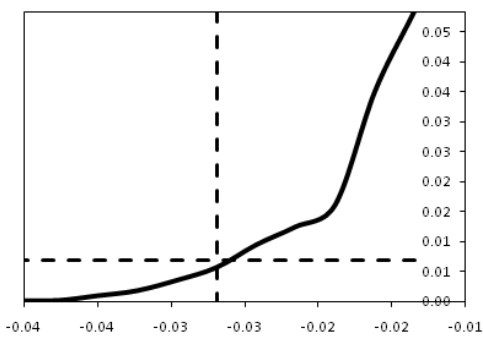

(f) Mobility of heads older than 45 vs age premium $\left(\alpha_{4}\right)$

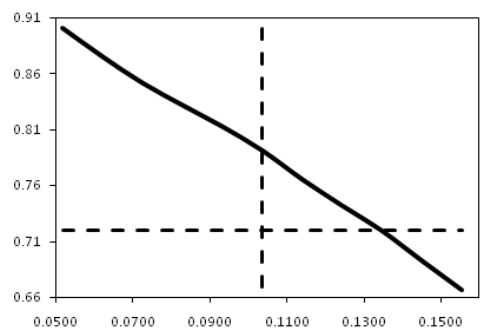

(i) No of times households buy a house vs cost of buying $\left(q_{b}\right)$

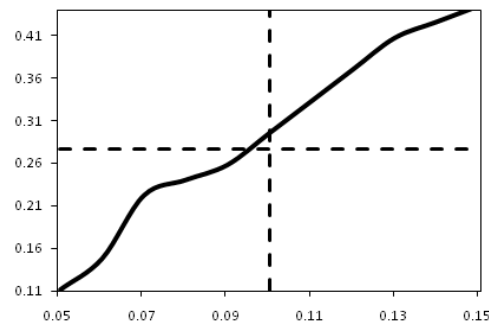

(l) Income Variance vs Variance of Shocks in region 1

Vertical dashed line shows point estimate, horizontal dashed line shows data moment. Solid line shows how a particular moment in the model deviates from the corresponding moment in the data as the parameter is moved away from the point estimate, fixing the remaining structural parameters. 
Figure 4: Model Fit: Total Labor Income Process

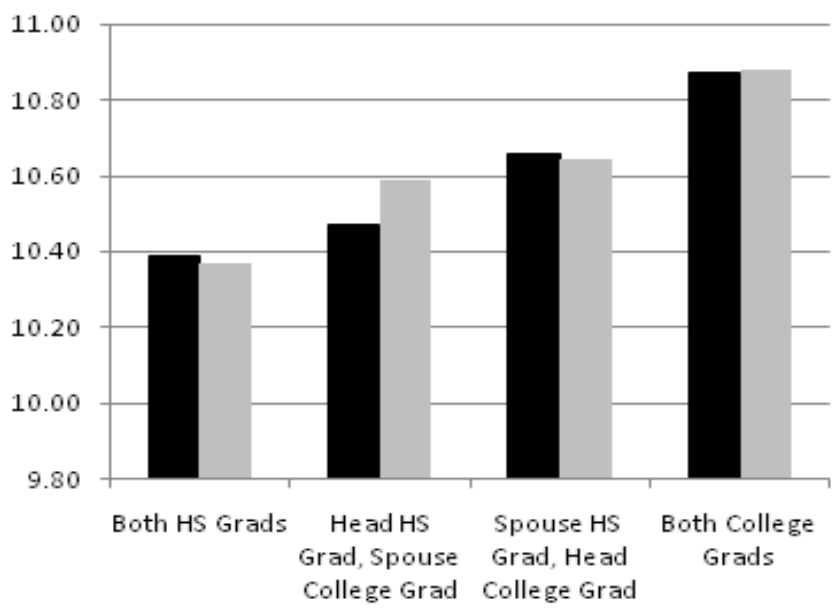

(A) Average Labor Income by Education

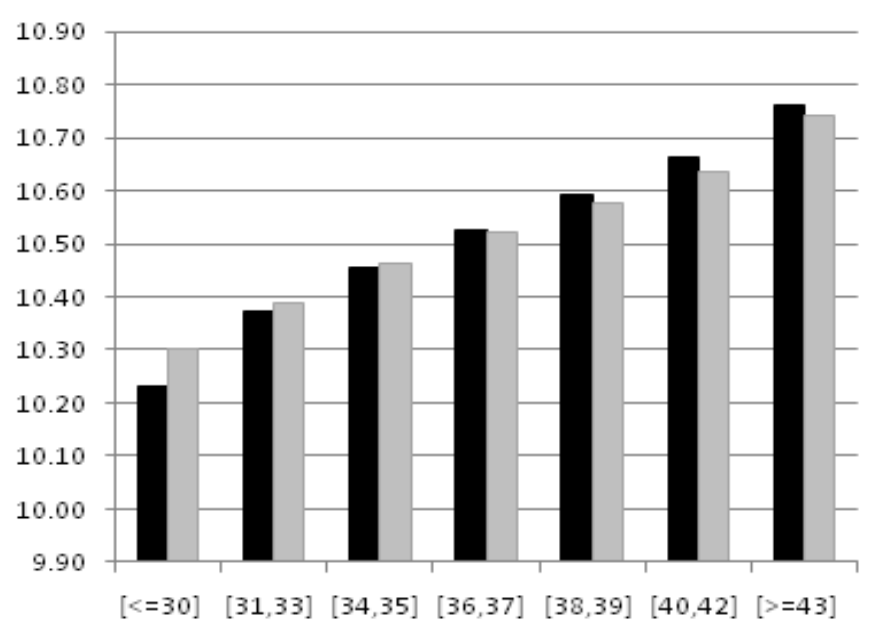

(C) Average Labor Income by Head's Age

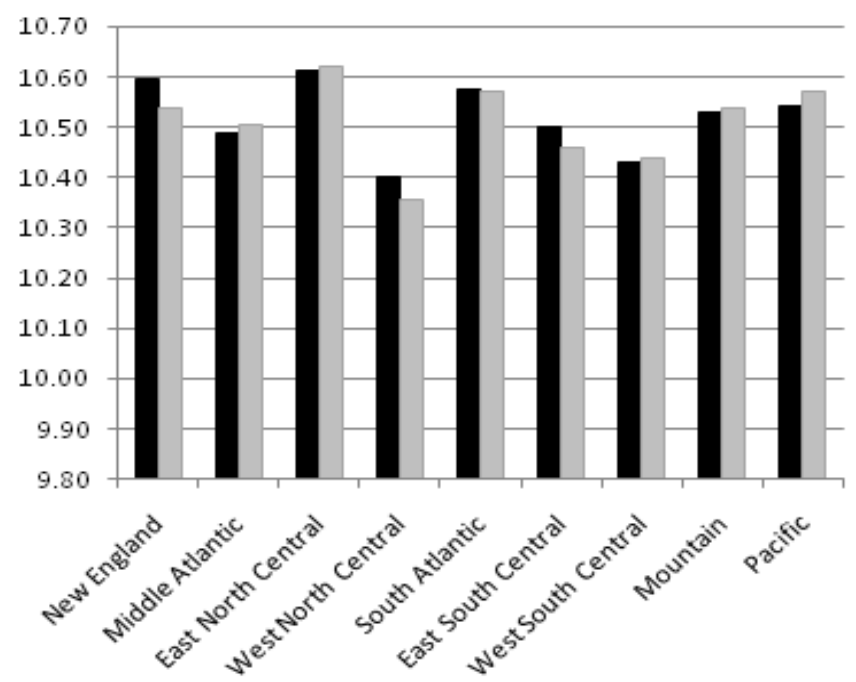

(B) Average Labor Income by Region

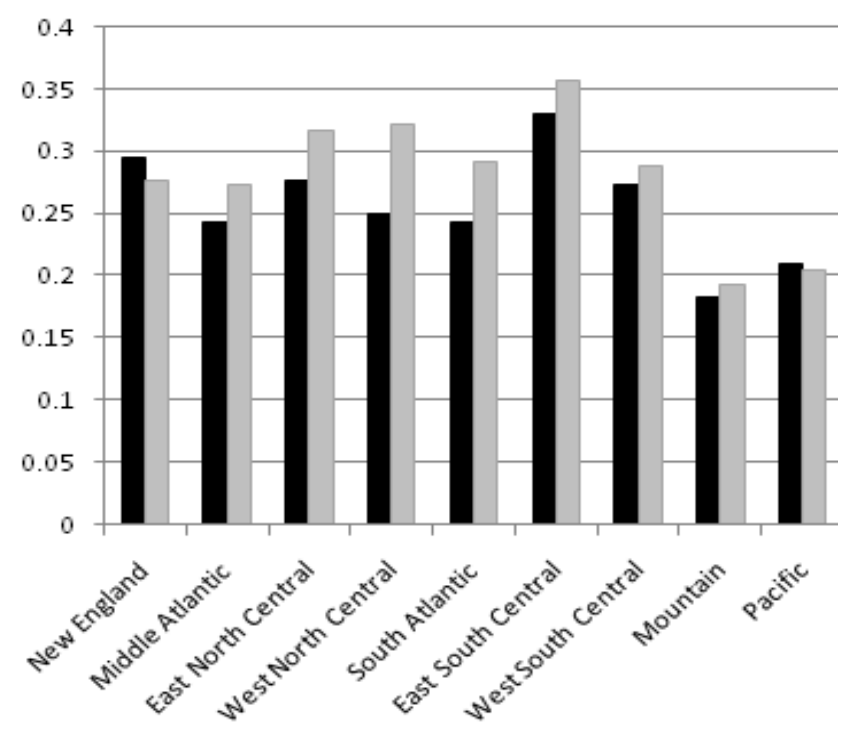

(D) Std Dev of Labor Income by Region 
Figure 5: Robustness Check: Distribution of Labor Income and Housing Dynamics

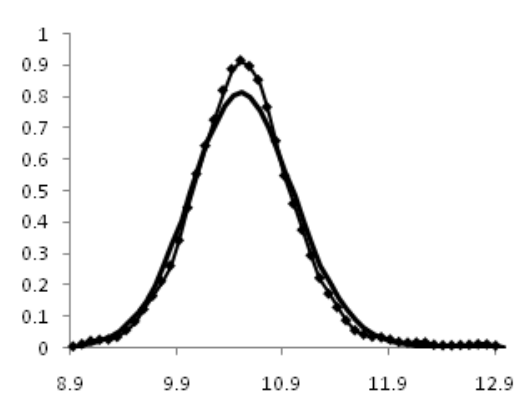

(a) Income Distribution

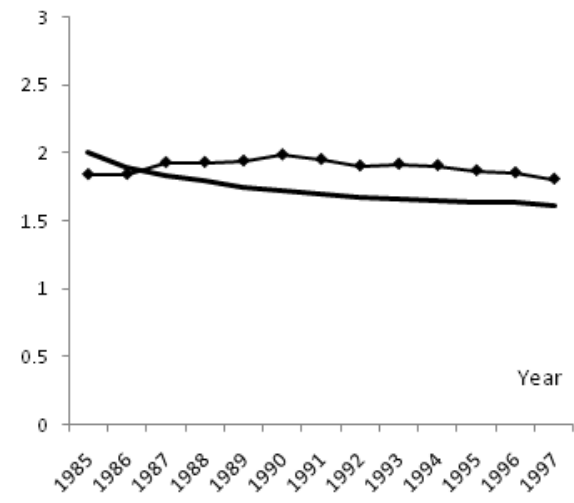

(c) Average Home Value-to-Income ratio

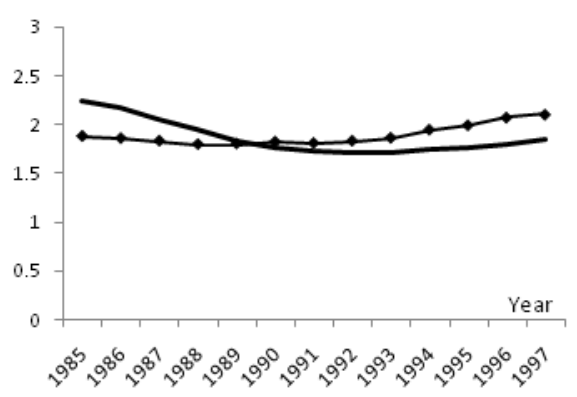

(e) Rooms per capita

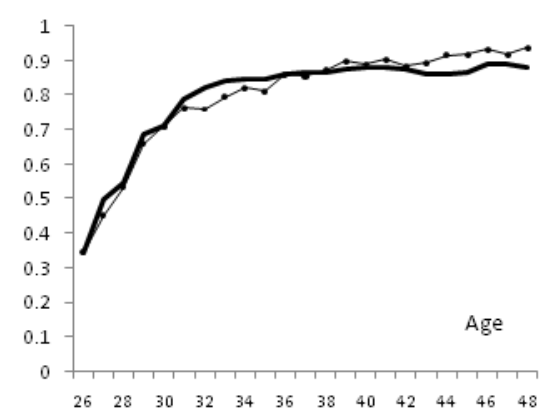

(b) Homeownerwhip rates

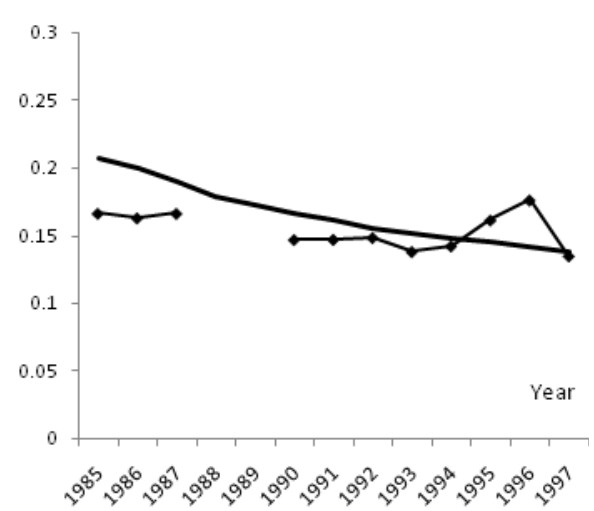

(d) Average Rent-to-Income ratio

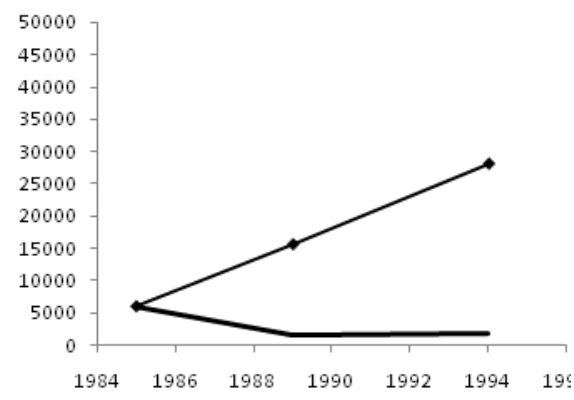

(f) Net Savings

-Model $\rightarrow$ Data 